\title{
Fiscal Year 1995 Final Report For TTP SR-1320-04 (U)
}

by

C. A. Cicero

Westinghouse Savannah River Company

Savannah River Site

Aiken, South Carolina 29808

D. F. Bickford

J. C. Marra

This paper was prepared in connection with work done under the above contract number with the U.S. Department of Energy. By acceptance of this paper, the publisher and/or recipient acknowledges the U.S. Government's right to retain a nonexclusive, royalty-free license in and to any copyright covering this paper, along with the right to reproduce and to authorize others to reproduce all or part of the copyrighted paper.

\section{MASTER}




\section{DISCLAIMER}

This report was prepared as an account of work sponsored by an agency of the United States Government. Neither the United States Government nor any agency thereof, nor any of their employees, makes any warranty, express or implied, or assumes any legal liability or responsibility for the accuracy, completeness, or usefulness of any information, apparatus, product, of process disclosed, or represents that its use would not infringe privately owned rights. Reference herein to any specific commercial product, process, or service by trade name, trademark, manufacturer, or otherwise does not necessarily constitute or imply its endorsement. recommendation, or favoring by the United States Government or any agency thereof. The views and opinions of authors expressed herein do not aecessarily state or reflect those of the United States Government or any agency thereof.

This report has been reproduced directly from the best available copy.

Available to DOE and DOE contractors from the Office of Scientific and Technical Information. P. O. Box 62, Oak Ridge, TN 37831; prices available from (615) $576-8401$.

Available to the public from the National Technical Information Service, U. S. Department of Commerce, 5285 Port Royal Rd., Springfield. VA 22161 


\section{DISCLAMMER}

Portions of this document may be illegible in electronic image products. Images are produced from the best available original document. 


\title{
Westinghouse Savannah River Company Savannah River Technology Center
}

WSRC-TR-95-0395
Revision 0

Keywords: LDR, RCRA, Vitrification, Organics, Durability, Mercury, Low level mixed wastes, Glass

September 30, 1995

\section{FISCAL YEAR 1995 FINAL REPORT FOR TTP SR-1320-04 (U)}

\author{
Connie A. Cicero, Dennis F. Bickford, and James C. Marra \\ Westinghouse Savannah River Company \\ Savannah River Technology Center \\ Aiken, South Carolina
}

\section{Summary}

The purpose of this Technical Task Plan (TTP) in fiscal year 1995 was to develop vitrification technology for application to mercury and organic waste streams, which are considered problem streams for a large portion of the DOE complexes. In addition, efforts were continued for pilot-scale demonstrations on Rocky Flats Plant (RFP) Precipitate sludge, and Los Alamos National Laboratory (LANL) TA50 sludge, which was a carry-over of fiscal year 1994 activities.

Crucible-scale studies were performed on mercury and organic waste streams to determine the optimum glass compositions. The optimal compositions were then used to treat actual wastes on a bench-top scale. Reports were written to summarize the data and results from the mercury and organic studies.

The pilot-scale studies with RFP and LANL simulated sludge used glass compositions determined in fiscal year 1994 studies. The pilot-scale studies 
were attempted in the EnVitCo cold-top melter and the Stir-Melter ${ }^{\circledR}$ stirred melter at the DOE/Industrial Center for Vitrification Research (Center). The results from these tests are being compiled by the graduate students and will be transmitted at a later date.

The fiscal year 1995 TTP also originally called for pilot-scale studies with the mercury and organic waste streams and for purchasing of a Russian Hybrid melter. However, funding limitations did not allow any new pilot scale studies to be performed or the melter to be purchased. Instead, a summary of the pilotscale studies to date with mercury and organic streams was compiled, and the Russian melter was purchased with other DOE-HQ funds.

A summary of the waste stream testing on both the crucible and pilot scale is given in the following table.

\begin{tabular}{|c|c|c|l|}
\hline \multirow{2}{*}{ Waste Stream } & \multicolumn{2}{|c|}{ Crucible Scale } & \multirow{2}{*}{ Pilot Scale } \\
\cline { 2 - 3 } & Surrogate & Actual & \\
\hline Hg Contaminated Soil & $\mathrm{X}$ & $\mathrm{X}$ & \\
\hline Hg Sludges & & & Documentation \\
\hline $\begin{array}{c}\text { Cation/Anion Ion } \\
\text { Exchange Resin }\end{array}$ & $\mathrm{X}$ & $\mathrm{X}$ & \\
\hline Resorcinol Resin & SRS Funds & & Documentation \\
\hline RFP Sludge & FY 94 & & EnVitCo \& SM \\
\hline LANL Sludge & FY 94 & & EnVitCo \\
\hline
\end{tabular}

Funding and support for several off site projects continued in FY95. A major effort involved the continuation of crucible studies to define the glass making region of the $\mathrm{CaO}-\mathrm{Fe}_{2} \mathrm{O}_{3}-\mathrm{SiO}_{2}$ system, with emphasis on durability testing of the glasses. These glasses were also used to compare the accuracy of X-ray Fluorescence (XRF) and Inductively Coupled Plasma-Emission Spectroscopy (ICPES) for chemical composition analyses of glass. Funding from this TTP was also used to continue a Cooperative Research and Development Agreement (CRADA) between EnVitCo, Scientific Ecology Group (SEG) Inc., and SRS for ash vitrification studies. Other smaller efforts at Clemson focused on creep resistance studies with Inconel 690 (a material used in melter and offgas components) and fuzzy logic control system studies.

Eight of the ten milestones were completed for this TTP. The two milestones associated with purchasing the Russian melter (\#4 and \#7) were not completed 
due to funding limitations for this TTP, but the melter was ordered. The cost study report milestone (\#6) was combined with the advanced melter report milestone (\#8) for cost efficiency. Lastly, milestone \#9, which required a summary of the pilot scale studies with mercury and organic simulated wastes, was completed by documenting previously performed pilot-scale studies, since sufficient funding to perform new studies was not available.

\section{Mercury Contaminated Soil Studies}

Two samples of mercury contaminated soil were obtained from excavation operations at the SRS. One of the samples was below the TCLP limits for mercury, while the other contained about $264 \mathrm{ppm}$ of mercury. These samples were selected because of complex wide soil disposal problems and the presence of mercury. Crucible studies with simulated soil had already been performed at the Savannah River Technology Center (SRTC) during fiscal year 1994. From these studies, acceptable glass compositions with waste loadings varying from 43 to $58 \mathrm{wt} \%$ were found. Of the five glasses, the soda-lime-silica glasses seemed to produce the most durable glasses.

Based on these findings, test melts with the low mercury SRS soil were conducted using the two highest waste loading soda-lime-silica compositions. Another test melt with $60 \mathrm{wt} \%$ soil was also conducted. All of these compositions were melted at $1150^{\circ} \mathrm{C}$, since this temperature was determined to produce acceptable glass in previous studies, and all contained $\mathrm{Na}_{2} \mathrm{CO}_{3}$ and $\mathrm{CaCO}_{3}$ as glass additives. Visual inspection of the melted feed indicated that none produced homogeneous glass, but the $60 \mathrm{wt} \%$ glass was closest to being homogeneous. Another melt was made with $80 \mathrm{wt} \%$ soil since the highest loading seemed to be the closest in appearance to glass. This composition also did not make glass.

Attempts were then made to melt the $60 \mathrm{wt} \%$ soil glass at $1350^{\circ} \mathrm{C}$ to see if all constituents could be vitrified. This produced a light blue homogenous glass with a minimum white layer $\left(\mathrm{SiO}_{2}\right)$ around the crucible interface. To try and eliminate the white layer $\left(\mathrm{SiO}_{2}\right)$, a melt was made at the same waste loading but with a higher sodium to calcium ratio since $\mathrm{Na}_{2} \mathrm{O}$ tends to make $\mathrm{SiO}_{2}$ more soluble. This composition produced a green-blue homogeneous glass, which also had a small white layer.

The Product Consistency Test (PCT) was performed on the $60 \mathrm{wt} \%$ soil glass to determine the durability in a neutral environment. This test is the standard protocol for measuring durability of High Level Waste (HLW) glasses. The elemental releases were well below the Environmental Assessment (EA) glass (the benchmark glass for $\mathrm{HLW}$ ) releases for $\mathrm{B}, \mathrm{Na}, \mathrm{Si}$, and $\mathrm{Li}$. Thus, it was determined that this was the optimum processing composition. 
This glass composition ( $60 \mathrm{wt} \%$ soil, $16 \mathrm{wt} \% \mathrm{CaCO}_{3}$, and $24 \mathrm{wt} \% \mathrm{Na}_{2} \mathrm{CO}_{3}$ ) was used for the high mercury soil vitrification studies. In order to vitrify this soil sample, a mercury collection system had to be fabricated and installed on the furnace because of the mercury volatility at elevated temperatures. The intent of the collection system was to capture the volatilized mercury and convert it to mercuric sulfide, which is a stable form of mercury that can be disposed.

The glass product produced will be subjected to the PCT to determine alkaline durability. The TCLP will also be performed to determine if mercury leaches from the glass or offgas products $\left(\mathrm{Hg}_{2} \mathrm{~S}\right)$. Once acceptable processing conditions are verified, the results will be compiled. Complete details of the studies will be found in "Bench Scale Studies with Mercury Contaminated SRS Soil". If successful, this technology will be able to be used with most vitrification systems to capture and convert the mercury present to a stable form, while simultaneously converting the remaining waste into a stable waste form.

\section{Ion Exchange Resin (Cation/Anion) Studies}

Crucible studies with clean SRS Reactor basin ion exchange resin using the $\mathrm{CaO}$ $\mathrm{Fe}_{2} \mathrm{O}_{3}-\mathrm{SiO}_{2}$ and Iron-Phosphate glass systems were performed by SRTC. The resin used was a cation/anion combination and was typical of resins used to treat reactor basin waters throughout the DOE complex, as well as in the commercial reactor sector. The $\mathrm{CaO}-\mathrm{Fe}_{2} \mathrm{O}_{3}-\mathrm{SiO}_{2}$ glass studies attempted to directly vitrify the untreated resin. Although the glasses produced had acceptable durabilities and were homogeneous, the success was limited by the relatively low resin loading obtained in the glass. The best loading was $0.202 \mathrm{~g}$ resin/g glass produced or $20 \mathrm{wt} \%$ resin.

For the Iron-Phosphate glass studies, pre-treatment of the resin was performed to try to maximize waste loading. The pre-treatment used was a nitricphosphoric acid oxidation process. This process was able to completely oxidize and destroy the organics and the resin at temperatures of $190^{\circ} \mathrm{C}$ and pressures of 5-10 psi. For a quick test, 60 grams of resin were completely dissolved in 200 $\mathrm{ml}$ of nitric-phosphoric acid solution. Approximately $58 \mathrm{wt} \%$ of the solution was mixed with iron, sodium, and barium compounds for a total resin loading of about $15 \%$. This loading could have been higher if more time was available to continue the resin oxidation, since the solution had not reached a saturation point. The batch was melted at $1150^{\circ} \mathrm{C}$ for 4 hours and produced homogenous glass. Durability results, as determined by the PCT, indicated that the glass had very minimal glass matrix component releases. The PCT results could not be directly compared to the HLW EA glass PCT results because the resin glass did not contain typical HLW glass components. 
After the success of the clean resin oxidation and vitrification process, a sample of spent resin was obtained from the Reactor facilities. This spent resin was removed from a deionizer bed presently in use in the Reactor basins and contained small amounts of Cs and Sr. Pre-treatment of the resin was performed using the nitric-phosphoric oxidation method. Maximum destruction ratio tested was 600 grams of resin to $200 \mathrm{ml}$ of solution. This oxidation solution was then vitrified using the same glass additives and melting processing parameters as before. The final product was a homogeneous black glass. The PCT is being performed to determine if durability is comparable to the clean resin glass. Leaching of the radioactive components will also be monitored. Two TCLPs will be performed on the final glass product to determine if any of the organic material or $\mathrm{Ba}$ leaches from the glass. If minimal or no organics are leached, this will indicate that the processes successfully destroyed the organics and/or that the residual organics were entrained in the glass matrix.

A summary of the resin studies using the $\mathrm{CaO}-\mathrm{Fe}_{2} \mathrm{O}_{3}-\mathrm{SiO}_{2}$ and Iron-Phosphate glass systems is being compiled in WSRC-TR-95-0394, Revision 0, "Savannah River Site Reactor Basin Ion Exchange Resin Bench Scale Studies".

The results of these bench scale studies will be transmitted to the Reactor facilities for consideration as an alternative disposal method for their spent resin. At present, their resin is being stored for later disposal as the deionizer beds are changed. The results from these tests indicate that significant cost savings could be realized by using the oxidation-vitrification process to stabilize the resin because of the significant volume reduction obtainable. Added benefit would also arise from the stabilization of the radioactive and organic components. This technology could be easily transferred to the commercial sector for use with stabilizing their organic ion exchange resins. Capital investment would not be very high because of the fact that a large, continuously fed melter is not needed. For the process described, the oxidation treatment could be performed in a small reaction vessel, the melter could be a batch melter, and a small offgas system could be installed to treat the acidic and radioactive volatilized components.

\section{Mercury Sludge Studies}

Mercury is present in radioactive waste sludges due to the use of mercuric nitrate as a catalyst during nitric acid dissolution of spent fuel rods. Since mercury decomposes at temperatures much less than radioactive glass melt temperatures, any mercury present at the time of vitrification would exit the melter in the offgas. Therefore, one option is to remove most of the mercury prior to vitrification by reduction and steam stripping. 
In order to determine the effectiveness of mercury removal before feeding, pilot-scale trials with simulated radioactive sludge containing mercury were performed at the TNX facility in the Integrated DWPF Melter System (IDMS). The IDMS facility contains a complete feed preparation, melter, and offgas system.

Numerous trials have been performed with mercury in the feed to determine how the feed process, melter operation, glass quality, and offgas products would be affected. All trials indicated that mercury was successfully stripped from the feed to the melter in the feed preparation process. Melt rates and melter operating conditions were not affected by the addition of mercury. In all cases, homogeneous glass was produced that was typical in behavior and chemical composition to glasses made without mercury additions. Durability results, as determined by the PCT, were well below the HLW EA glass PCT releases for B, $\mathrm{Na}$, and $\mathrm{Li}$ and comparable to other fabricated glasses without mercury. Very little mercury was actually found in the melter offgas line.

Mercury balances were performed around the system components for the runs and showed good closure. In addition, mercury decontamination factors were also calculated. Some were better than expected, while others were lower than expected. Steam stripping efficiencies varied, as did endpoint mercury concentrations. Overall, the non-mercury designated runs performed better with steam stripping and with meeting the desired endpoint mercury concentrations. These runs used nitric acid as the reductant in the feed preparation process as opposed to formic acid.

Additional information on the IDMS pilot-scale studies can be found in WSRCTR-93-0163, "Integrated DWPF Melter System (IDMS) Campaign Report Mercury Operations", and WSRC-RP-91-371, "Durability of Glasses from the Mercury Doped Integrated DWPF Melter System (IDMS) Campaign". For additional information on the mercury removal process, see "Mercury Reduction and Removal During High Level Radioactive Waste Processing and Vitrification" in Scientific Basis for Nuclear Waste Management IV (Eibling and Fowler, 1982).

A compilation of the studies performed can also be found in WSRC-TR-95-0404, "Summary of Pilot-Scale Activities with Mercury Contaminated Sludges", given as Attachment $I$.

\section{Ion Exchange Resin (Resorcinol) Studies}

In order to provide an alternative treatment for the radioactive wastewater sludges and supernates, a resorcinol ion exchange resin was developed by SRTC. This resin is a Cs-specific resin and was proposed for use instead of the sodium tetraphenylborate precipitate process currently being used for treatment of 
HLW. Using the tetraphenylborate precipitate process also requires benzene destruction and introduces undesirable chemicals into the vitrification system.

Effectiveness of this treatment process for removing Cs was proven, and the proposed disposal option was vitrification with the rest of the HLW feed. Vitrification tests were performed on a crucible-scale by SRTC to prove that the resin could be mixed with the simulated radioactive sludge and glass frit feed and successfully vitrified. Studies found that 5 grams of this resin could be successfully incorporated in 100 grams of glass produced. Pilot-scale studies were also performed using this resin and similar feed compositions at the SRTC and the Center. Both tests proved the feasibility of vitrification for treatment of resin. The resulting glass product was not adversely affected, nor were the melter processing conditions.

In the SRTC tests, the SRTC mini-melter was operated under normal operating conditions $\left(1150^{\circ} \mathrm{C}\right.$ melt temperature and offgas collection system functioning). The resin was thoroughly mixed with glass frit and a simulated radioactive sludge. Three trials were performed. Two were batch type runs and one was a continuous run. In one of the batch type runs, resin was not added to the feed, so baseline conditions could be established. Both of the resin trials had similar results. Resin loadings were the same as obtained in the crucible studies ( $5 \mathrm{~g}$ of resin per $100 \mathrm{~g}$ of glass produced). The glass redox ratio was increased as more resin was incorporated into the glass matrix and was greater during continuous feed. The more reduced glasses had slightly poorer durability compared to the resin free glasses. Overall, the test showed that vitrification of the resin was possible, a durable glass could be produced, and that melter operating conditions were not affected. For additional details, see "Summary of Pilot-Scale Activities with Resorcinol Ion Exchange Resin", WSRC-TR-95-0403.

Studies performed with the resorcinol resin at the Center included pilot-scale studies, as well as crucible studies to determine maximum resin loading. Crucible results were used to develop a formula for calculating possible resin loadings, and the maximum demonstrated resin loading was 4.91 grams of resin/100 grams of glass produced. After the optimum loadings and operating conditions for the Stir-Melter were determined, pilot-scale studies were performed. During the pilot-scale studies, the resin was mixed with glass frit, simulated radioactive sludge, and simulated radioactive supernate obtained from SRTC. This composition was only slightly different than the feed used in the SRTC pilot-scale studies because of the addition of the simulated radioactive supernate, but it was not felt that the small amount of additional alkali metals present would affect the glass behavior.

In the Center pilot-scale studies, a total of $88.18 \mathrm{~g}$ of Cs were fed to the melter, and the total glass retention was about $82.17 \mathrm{~g}$ of $\mathrm{Cs}$ or $82.3-93.2 \%$. An 
additional 2.225 grams of Cs or $2.46-2.80 \%$ Cs was captured in the offgas system. Most of it was captured in the bubbler. Complete details of these studies can be found in the graduate thesis entitled "Vitrification of CsContaminated Organic Ion Exchange Resin" by Thomas N. Sargent.

A compilation of both the SRTC and Center reports on the resin vitrification demonstrations can be found in "Summary of Pilot-Scale Activities with Resorcinol Ion-Exchange Resin", which can be found as Attachment II.

\section{DOE/Industrial Center for Vitrification Research}

Fiscal year 1995 activities at the DOE Center included pilot scale studies with simulated RFP precipitate and LANL TA-50 sludge. These demonstrations completed the waste water treatment sludge demonstrations. The RFP demonstrations were completed in the EnVitCo melter (50 wt\% sludge loading). A large carry-over of sodium sulfate was seen in the offgas. This caused numerous offgas line pluggage problems and some devitrification in the glass. RFP demonstrations were started in the Stir-melter ( $44 \mathrm{wt} \%$ sludge), but could not be completed due to mechanical difficulties with the melter. Three impellers failed during operation. Documentation of the glass and offgas characterization, as well as operating conditions, are currently being completed.

The LANL demo was completed in the EnVitCo melter. Some problems were experienced with operating because of the high temperatures needed to melt the glass, and other problems were experienced with devitrification in cold spots of the melter. Documentation of the glass and offgas characterization, as well as operating conditions, are currently being completed.

A DC arc melter from EPI was also installed at the Center after it was purchased with capital funding during the Economic Development forum. Limited checkout testing with this melter was performed to ensure operability. These tests were performed on soil feeds.

The monthly reports for the FY95 activities at the Center are contained in Attachment III. These monthly reports provide summaries of the project accomplishments, milestones achieved, and problems encountered in support of TTP SR-1320-04.

\section{$\mathrm{XRF}$ and $\mathrm{CaO}-\mathrm{Fe}_{2} \mathrm{O}_{3}-\mathrm{SiO}_{2}$ Studies}

Real time characterization studies with X-ray Fluorescence (XRF) were continued. ICPES is currently used by many laboratories to analyze the wastes and glass produced, however, this is usually a slow process due to the dissolutions required and the amount of time needed to run the analyses. Work was 
continued at Clemson University - Environmental Systems Engineering Department to better refine XRF techniques and to better define durable glasses. These studies are using an experimentally determined glass composition space, which consists of six variable components $\left(\mathrm{SiO}_{2}, \mathrm{Al}_{2} \mathrm{O}_{3}, \mathrm{~B}_{2} \mathrm{O}_{3}, \mathrm{Fe}_{2} \mathrm{O}_{3}, \mathrm{Na}_{2} \mathrm{O}\right.$, and $\mathrm{CaO})$ and three fixed level hazardous components $(\mathrm{BaO}, \mathrm{PbO}$, and $\mathrm{NiO})$.

Continued comparisons between XRF and ICPES analysis showed no statistical difference in the results between the two analytical methods. This further confirms the accuracy of the XRF method. This comparison was also made for glasses produced during some of the wastewater treatment sludge vitrification demonstrations. In the cases where borosilicate glasses were made, boron was determined from mass balance, and in cases where lithia-soda-lime glasses were made, lithia was determined from mass balance. Excellent agreement was also found for these analyses comparisons.

In durability testing, the glass-former to glass-modifier (F/M) molar ratio was found to have the greatest effect on PCT results. The formers used included $\mathrm{SiO}_{2}$, $\mathrm{Al}_{2} \mathrm{O}_{3}$, and $\mathrm{B}_{2} \mathrm{O}_{3}$ and the modifiers included $\mathrm{Na}_{2} \mathrm{O}, \mathrm{CaO}, \mathrm{BaO}, \mathrm{NiO}$, and $\mathrm{PbO}$. As the $\mathrm{F} / \mathrm{M}$ ratio increased, the normalized release was found to decrease between one and two orders of magnitude (better durability). If $\mathrm{Fe}_{2} \mathrm{O}_{3}$ content was considered with the F/M ratio, the normalized release decreased one order of magnitude at low $\mathrm{F} / \mathrm{M}$ with higher $\mathrm{Fe}_{2} \mathrm{O}_{3}$ content, but had no effect on the higher $\mathrm{F} / \mathrm{M}$ ratios as the $\mathrm{Fe}_{2} \mathrm{O}_{3}$ content increased. Durability increased with 10 mole percent additions of $\mathrm{Al}_{2} \mathrm{O}_{3}$ with high $\mathrm{Fe}_{2} \mathrm{O}_{3}$ content, but showed no advantage at low $\mathrm{Fe}_{2} \mathrm{O}_{3}$ content. The $\mathrm{Na} 2 \mathrm{O} / \mathrm{CaO}$ ratio also had an important effect on durability. Normalized releases increased up to two orders of magnitude at low ratios, while no effects were observed for glasses with high ratios. $\mathrm{B}_{2} \mathrm{O}_{3}$ additions had little effect. Overall, it was found that relatively durable glasses could be produced with a low $\mathrm{F} / \mathrm{M}$ ratio if they also had a low $\mathrm{Na}_{2} \mathrm{O} / \mathrm{CaO}$ ratio and contained 10 mole percent $\mathrm{Al}_{2} \mathrm{O}_{3}$.

Papers were presented at Waste Management 95, the 97th annual American Ceramic Society Symposium, and Emerging Technologies in Hazardous Waste Management VII Conference. Copies of the papers are containegd as Attachment. IV.

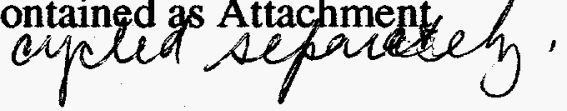

Complete details of the methods used for fabrication and testing of most of the glasses can be found in the graduate thesis by R.G. Ragsdale. This is given as Attachment V, "XRF and Leaching Characteristics of Waste Glasses Derived from Wastewater Treatment Sludges". This thesis served as the starting basis for all of the work performed to determine the XRF and ICPES correlation and also to determine the durable processing region. 


\section{CRADA for Ash Vitrification Studies}

The CRADA signed between Westinghouse Savannah River Company (WSRC), SEG, and EnVitCo was continued in fiscal year 1995. The purpose of this CRADA was to perform vitrification studies on simulated and actual low-level radioactive ash wastes resulting from incineration at SEG using an EnVitCo WASTE-VITTM joule heated melter. In this year, many delays were experienced on SEG's part. However, WSRC was able to analyze the radioactive ash for the studies to be performed. From this analysis, a simulated ash was formulated and used for glass batching and melting. The compositions tested had waste loadings from 30 to $40 \mathrm{wt} \%$ and were melted at $1350^{\circ} \mathrm{C}$. After the best composition was determined, it was transmitted to SEG and attempts to make crucible-scale glasses with the actual ash were started.

Tests to examine the effects of high salt content glass melts on the durability of typical materials of construction for glass melters were also completed. Corrosion at the melt-line was the most severe in all tests. In general, the presence of elevated chloride levels caused the most significant corrosion to Inconel alloys and high chromium content refractories. Large increases in corrosion rates with increasing melt temperature were also observed.

A more detailed account of these corrosion studies can be found in "Corrosion Assessment of Refractory Materials for Waste Vitrification" by J.C. Marra, et. al. and "Vitrification of Wastes Containing Salts" by J.C. Marra and M.K. Andrews.

In the next fiscal year, the crucible studies with the actual ash will be continued. Once a homogeneous and durable composition is determined, vitrification demonstrations in the EnVitCo melter using a surrogate ash and the proposed compositions will be performed. Radioactive demonstrations will be completed once the surrogate tests are finished. After all testing and analyses is complete, a final report summarizing the activities performed will be issued.

Funding from this TTP provided WSRC's share of the CRADA, with WSRC bringing glass expertise to the agreement. Completion of the above mentioned tasks met two milestones. Three milestones remain to be completed and are scheduled for completion by $1 / 96$.

\section{Inconel Creep Resistance Studies}

The SCUREF task with Clemson involving the study of high temperature tensile and creep properties of Inconel 690 were continued in FY95. One of the main goals of these studies was to extend existing lower temperature data for the alloy. These studies were completed in FY95 and are now being documented. Some of the findings will be briefly discussed below. 
1) Creep of the Inconel 690 divides into three regions: $\angle 950^{\circ} \mathrm{C} ; 950-1100^{\circ} \mathrm{C}$; and $>1100^{\circ} \mathrm{C}$. Microstructural changes, in particular grain growth, appear to be the principal factor controlling the creep. The transition from polycrystalline to large multi-grain behavior controls creep at elevated temperatures.

2) Creep fixtures of Alloy 754 have suffered oxidation degradation at $1200^{\circ} \mathrm{C}$. Alloys with more aluminum provide some advantage under these conditions. Inconel 617 (1.7\% Al), modified Inconel 690 ( 3\% Al), and Alloy 3003 (modified 754) are some suggested alternatives.

3) Erosion-corrosion concerns have led glass manufacturers to investigate arcsprayed Inconel 72 overlays; Inconel 758, a dispersion-strengthened Inconel 690 welded by MIG techniques; and alloys Inconel 671 and Duralloy Blaw-Knox 50/50. Each may be applicable to the stirred melter.

4) Gaseous nitrogen in any form may be a problem with the high $\mathrm{Cr}$ alloys. Thus nitrogen is not an "inert" gas problem for avoiding oxidation in these alloys.

Publications/Presentations Related to This TTP

C. A. Cicero, D.F. Bickford, C.M. Jantzen, D.M. Bennert, and T.J. Overcamp, "Savannah River Site Simulated M-Area Sludge Vitrification Demonstration", WSRC-RP-93-659, Westinghouse Savannah River Company, Aiken, SC (May 14, 1993).

\section{C.A. Cicero, "Run Plan for Simulated M-Area Sludge Vitrification} Demonstration", WSRC-RP-93-902, Westinghouse Savannah River Company, Aiken, SC (June 22, 1993).

C.M. Jantzen, J.B. Pickett, and W.G. Ramsey, "Reactive Additive Stabilization Process (RASP) for Hazardous and Mixed Waste Vitrification", WSRC-MS-93-118, Proceedings of the Second International Mixed Waste Symposium, Baltimore, MD, August 17-20, 1993.

D.M. Bennert, T.J. Overcamp, T.N. Sargent, and J.L. Resce, "Pilot Scale Vitrification Studies on Hazardous and Mixed Wastes", Proceedings of the Second International Mixed Waste Symposium, Baltimore, MD, August 17-20, 1993.

K.C. Compton, D.M. Bennert, and D.F. Bickford, "Regulatory Issues in Vitrification Treatment Research", Proceedings of the 95th Annual American Ceramic Society Convention, Symposium VIII, April 19-22, 1993. 
D.M. Bennert, T.J. Overcamp, T.N. Sargent, and D.F. Bickford, "Pilot Scale Vitrification Studies of Hazardous and Mixed Waste", Proceedings of the 95th Annual American Ceramic Society Convention, Symposium VIII, April 1922, 1993.

D.M. Bennert, T.J. Overcamp, K.C. Compton, T.N. Sargent, and J.L. Resce, "Pilot Scale Treatability Tests for Vitrification of Hazardous and Mixed Wastes", International Conference on Incineration and Thermal Treatment Technologies, May 1993.

C.A. Cicero, D.F. Bickford, D.M. Bennert, and T.J. Overcamp, "Oak Ridge National Laboratory West End Treatment Facility Simulated Sludge Vitrification Demonstration", WSRC-RP-93-01111, Westinghouse Savannah River Company, Aiken, SC (August 23, 1993).

C.A. Cicero and K.E. Mottel, "QA Matrix for ORNL WETF Simulated Sludge Vitrification Demonstration", SRT-GTC-93-0060, Westinghouse Savannah River Company, Aiken, SC (September 14, 1993).

C.A. Cicero, "Run Plan for Simulated ORR WETF Sludge Vitrification Demonstration", WSRC-RP-94-00259, Westinghouse Savannah River Company, Aiken, SC (March 9, 1994).

M.K. Andrews and C.A. Cicero, "ORNL WETF Simulated Sludge Crucible Studies", WSRC-TR-93-647, Revision 0, Westinghouse Savannah River Company, Aiken, SC (December 3, 1993).

M.K. Andrews and C.A. Cicero, "ORR WETF Simulated Sludge Crucible Studies", WSRC-TR-93-647, Revision 1, Westinghouse Savannah River Company, Aiken, SC (March 15, 1994).

D.M. Bennert and D.F. Bickford, "Pilot Scale Demonstration of Vitrification of Surrogate F006 Wastewater Treatment Sludges", Proceedings of the Nuclear and Hazardous Waste Management International Topical Meeting, Atlanta, GA, April 14-18, 1994.

C.A. Cicero, "Devitrification Studies with ORR WETF Glasses", SRTGTC-94-0048, Westinghouse Savannah River Company, Aiken, SC (September 30, 1994).

T.N. Sargent, D.M. Bennert, T.J. Overcamp, D.F. Bickford, and C.A. Cicero, "Vitrification of Ion Exchange Resins", Proceedings of the 95th Annual American Ceramic Society Convention, Symposium VIII, April 19-22, 1993. 
D.M. Bennert, T.J. Overcamp, D.F. Bickford, C.M. Jantzen, and C.A. Cicero, "Demonstration of Vitrification of Surrogate EPA F006 Wastewater Treatment Sludges", Proceedings of the 96th Annual American Ceramic Society Convention, Symposium VIII, Indianapolis, IN, April 24-28, 1994.

C.A. Cicero, D.F. Bickford, D.M. Bennert, and T.J. Overcamp, "Rocky Flats Plant Precipitate Sludge Surrogate Vitrification Demonstration", WSRCRP-94-062, Westinghouse Savannah River Company, Aiken, SC (June 17, 1994).

C.A. Cicero and K.E. Mottel, "QA Matrix for Rocky Flats Plant Precipitate Sludge Surrogate Vitrification Demonstration", WSRC-TR-9400278, Westinghouse Savannah River Company, Aiken, SC (June 14, 1994).

C.A. Cicero, "Run Plan for RFP Precipitate Sludge Surrogate Vitrification Demonstration", WSRC-RP-94-00656, Westinghouse Savannah River Company, Aiken, SC (June 30, 1994).

M.K. Andrews and C.A. Cicero, "Simulated RFP Precipitate Sludge Crucible Studies", WSRC-TR-94-00107, Revision 0, Westinghouse Savannah River Company, Aiken, SC (May 20, 1994).

C.A. Cicero, D.F. Bickford, D.M. Bennert, and T.J. Overcamp, "Los Alamos National Laboratory Simulated Sludge Vitrification Demonstration", WSRC-RP-94-00780, Westinghouse Savannah River Company, Aiken, SC (September 30, 1994).

C.A. Cicero and M.K. Andrews, "Simulated LANL TA-50 Sludge Crucible Studies", WSRC-TR-94-00313, Westinghouse Savannah River Company, Aiken, SC (August 29, 1994).

C.A. Cicero and M.K. Andrews, "Simulated LANL TA-50 Sludge Crucible Studies", WSRC-TR-94-00313, Rev. 1, Westinghouse Savannah River Company, Aiken, SC (September 16, 1994).

C.A. Cicero and D.F. Bickford, "First Quarter Summary Report for TTP SR1-3-20-04", WSRC-TR-94-00034, Westinghouse Savannah River Company, Aiken, SC (January 13, 1994).

D.M. Bennert, "M-Area Surrogate Vitrification Study Interim Report on Glass Leachability", CUVP-RP-94-001, Clemson University - DOE Industrial Center for Vitrification Research, Anderson, SC (February 18, 1994). 
D.F. Bickford, "Selection of Melter Systems for the DOE/Industrial Center for Waste Vitrification Research", WSRC-TR-93-00762, Westinghouse Savannah River Company, Aiken, SC (December 31, 1993).

C.A. Cicero, D.F. Bickford, M.K. Andrews, and D.M. Bennert, "Interim Report on Land Disposal Leaching Results", WSRC-TR-94-00124, Westinghouse Savannah River Company, Aiken, SC (February 28, 1994).

C.A. Cicero, D.F. Bickford, M.K. Andrews, and D.M. Bennert "Second Quarter Summary Report for TTP SR1-3-20-04", WSRC-TR-94-00174, Westinghouse Savannah River Company, Aiken, SC (March 31, 1994).

J.L. Resce, R.G. Ragsdale, T.J. Overcamp, A.R. Jurgensen, C.A. Cicero, and D.F. Bickford, "XRF in Waste Glass Analysis and Vitrification Process Control, Part 1: Sample Preparation and Measurement Precision", Proceedings of the 96th Annual American Ceramic Society Convention, Indianapolis, IN, April 24-28, 1994.

C.A. Cicero, D.F. Bickford, M.K. Andrews, and D.M. Bennert "Third Quarter Summary Report for TTP SR1-3-20-04", WSRC-TR-94-00314, Westinghouse Savannah River Company, Aiken, SC (June 30, 1994).

C.A. Cicero, D.F. Bickford, M.K. Andrews, W.O. Crews, D.J. Meunier, C.C. Saur, R.G. Ragsdale, and J.L. Resce "Low-Level Mixed Waste Glass Compositional Limits Report”, WSRC-TR-94-00315, Westinghouse Savannah River Company, Aiken, SC (June 30, 1994).

J.L. Resce, R.G. Ragsdale, T.J. Overcamp, D.F. Bickford, and C.A. Cicero "Correlation of XRF and Conventional Methods for the Analysis of Waste Glass", Proceedings of the 95th Annual American Ceramic Society Convention, Symposium VIII, April 19-22, 1993.

D.F. Bickford, "Needs Driven Vitrification", Proceedings of the Nuclear and Hazardous Waste Management International Topical Meeting, Atlanta, GA, April 14-18, 1994.

D.M. Bennert and D.F. Bickford, "Pilot Scale Demonstration of Vitrification of Surrogate F006 Wastewater Treatment Sludges", Proceedings of the Nuclear and Hazardous Waste Management International Topical Meeting, Atlanta, GA, April 14-18, 1994.

C.A. Cicero, M.K. Andrews, and D.F. Bickford, "Comparison of TCLP and Long-term PCT Performance on LLMW Glasses", Proceedings of the 
Nuclear and Hazardous Waste Management International Topical Meeting, Atlanta, GA, April 14-18, 1994.

W.O. Crews and C.A. Cicero, "Defining the Glass Composition Limits for SRS Contaminated Soils", WSRC-TR-94-00451, Westinghouse Savannah River Company, Aiken, SC (September 21, 1994)

D.J. Meunier and C.A. Cicero, "Defining Waste Glass Composition Limits for the Calcia-Alumina-Silica Ternary System", WSRC-TR-9400452, Westinghouse Savannah River Company, Aiken, SC (September 21, 1994)

C.A. Cicero, D.F. Bickford, M.K. Andrews, D.M. Bennert, and J.C. Marra "Final Report for TTP SR1-3-20-04", WSRC-TR-94-00455, Westinghouse Savannah River Company, Aiken, SC (September 30, 1994).

R.G. Ragsdale, "XRF and Leaching Characterization of Waste Glasses Derived from Wastewater Treatment Sludge", Graduate Thesis for Clemson University - Environmental Systems Engineering, December 15, 1994.

K.J. Hewlett, "Vitrification Demonstration of West End Treatment Facility Mixed Waste Sludge", Graduate Thesis for Clemson University Environmental Systems Engineering, December 1994.

J.L. Resce, R.G. Ragsdale, T.J. Overcamp, D.F. Bickford, and C.A. Cicero, "The Effect of Chemical Composition on the PCT Durability of Mixed Waste Glasses from Wastewater Treatment Sludges", Proceedings of Waste Management 95, Tucson, AZ, February 27 - March 2, 1995.

J.L. Resce, R.G. Ragsdale, T.J. Overcamp, D.F. Bickford, and A.R. Jurgensen, "Elemental Analysis of Waste Glasses by X-ray Fluorescence Spectrometry", Proceedings of Waste Management 95, Tucson, AZ, February 27 - March 2, 1995.

D.F. Bickford, B.D. Helton, and G.S. Bumgarner, "Needs Driven Vitrification of Mixed Wastes", Proceedings of Waste Management 95, Tucson, AZ, February 27 - March 2, 1995.

C.A. Cicero, M.K. Andrews, and D.F. Bickford, "Vitrification Studies with DOE Low-Level Mixed Waste Wastewater Treatment Sludges", Proceedings of Waste Management 95, Tucson, AZ, February 27 - March 2, 1995.

D.F. Bickford and E. Skaar, "Thermodynamic Modeling of Volatility from Glass Melts", Proceedings of the 97th Annual American Ceramic Society Convention, Cincinnati, OH, April 30 - May 3, 1995. 
R.A. Wilson, T.J. Overcamp, D.M. Bennert, D.F. Bickford and C.A. Cicero, "Pilot Scale Vitrification Demonstration of Rocky Flats Plant Mixed Waste Sludge", Proceedings of the 97th Annual American Ceramic Society Convention, Cincinnati, OH, April 30 - May 3, 1995.

K.J. Hewlett, D.M. Bennert, T.J. Overcamp, and D.F. Bickford, "Vitrification of West End Treatment Facility Mixed Waste Sludge", Proceedings of the 97th Annual American Ceramic Society Convention, Cincinnati, OH, April 30 May 3, 1995.

D.F. Bickford, W.G. Ramsey, C.M. Jantzen, E. Skaar, and T. Taylor, "Structure Based Statistical Modeling of Waste Glass Durability", Proceedings of the 97th Annual American Ceramic Society Convention, Cincinnati, OH, April 30 - May 3, 1995.

P.R. Mundt and T.D. Taylor, "Annealing of Massive Vitreous Waste Forms", Proceedings of the 97th Annual American Ceramic Society Convention, Cincinnati, OH, April 30 - May 3, 1995.

J.L. Resce, R.G. Ragsdale, T.J. Overcamp, D.F. Bickford and C.A. Cicero, "Compositional Factors Affecting the Chemical Durability of Vitrified Wastewater Treatment Sludges", Proceedings of the 97th Annual American Ceramic Society Convention, Cincinnati, OH, April 30 - May 3, 1995.

J.L. Resce, T.J. Overcamp, A.R. Jurgensen, and D.F. Bickford, "XRF in Waste Glass Analysis and Vitrification Process Control, Part 3: Rapid and Accurate Chemical Analysis of Vitrified Wastewater Treatment Sludge Surrogates", Proceedings of the 97th Annual American Ceramic Society Convention, Cincinnati, OH, April 30 - May 3, 1995.

C.A. Cicero, D.F. Bickford, and W.O. Crews, Jr., "Defining the Glass Composition Limits for SRS Contaminated Soils", Proceedings of the Third Biennial Mixed Waste Symposium, Baltimore, MD, August 8-11, 1995.

C.A. Cicero, M.K. Andrews, D.F. Bickford, and D.J. Meunier, "Defining the Glass Composition Limits for the $\mathrm{CaO}-\mathrm{Al}_{2} \mathrm{O}_{3}-\mathrm{SiO}_{2}$ Ternary System", Proceedings of the Third Biennial Mixed Waste Symposium, Baltimore, MD, August 8-11, 1995.

C.A. Cicero, D.F. Bickford, W.O. Crews, Jr., A.L. Kielpinski, J.C. Marra, A. Applewhite-Ramsey, R.F. Schumacher, and T.L. Spatz, "Vitrification of Savannah River Site Contaminated Soils", Presented at ACS Emerging Technologies in Hazardous Waste Management VII Conference, Atlanta, GA, September 17-20, 1995. 
J.L. Resce, T.J. Overcamp, C.A. Cicero, and D.F. Bickford, "The Effect of Compositional Parameters on the TCLP and PCT Durability of Environmental Glasses", Presented at ACS Emerging Technologies in Hazardous Waste Management VII Conference, Atlanta, GA, September 17-20, 1995.

J.L. Resce, T.J. Overcamp, A.R. Jurgensen, and D.F. Bickford, "The Elemental Analysis of Environmental Waste Glass and Melter Feed with XRF Spectrometry", Presented at ACS Emerging Technologies in Hazardous Waste Management VII Conference, Atlanta, GA, September 17-20, 1995.

C.A. Cicero, D.F. Bickford, T.N. Sargent, M.K. Andrews, J.P. Bibler, N.E. Bibler, and C.M. Jantzen, "Summary of Pilot-Scale Activities with Resorcinol Ion Exchange Resin", WSRC-TR-95-403, Westinghouse Savannah River Company (September 30, 1995).

C.A. Cicero, N.D. Hutson, J.R. Zamecnik, M.E. Smith, D.H. Miller, J.A. Ritter, B.J. Hardy, and C.M. Jantzen, "Summary of Pilot-Scale Activities with Mercury Contaminated Sludges", WSRC-TR-95-403, Westinghouse Savannah River Company (September 30, 1995).

C.A. Cicero, "Savannah River Site Reactor Basin Ion Exchange Resin Batch-Scale Studies", WSRC-TR-95-0394, Westinghouse Savannah River Company (in preparation).

J.C. Marra, T.J. Overcamp, D.M. Bennert, T.N. Sargent, K.J. Hewlett, and R.A. Wilson, "Melter Performance During Surrogate Vitrification Campaigns at the DOE/Industrial Center for Vitrification Research at Clemson University", WSRC-TR-95-0412, Westinghouse Savannah River Company (September 29, 1995).

J.C. Marra, J.W. Congdon, A.L. Kielpinski, R.F. Schumacher, A.A. Ramsey, J. Etheridge, and R. Kirkland, "Corrosion Assessment of Refractory Materials for Waste Vitrification", Corrosion of Materials by Molten Glass, Ceramic Transactions Series, American Ceramic Society, Westerville, OH, 1995.

J.C. Marra and M.K. Andrews, "Vitrification of Wastes Containing Salts", Presented at Emerging Technologies in Hazardous Waste Management VII Conference, Atlanta, GA, September 17-20, 1995.

C.A. Cicero, "Batch-Scale Studies with Mercury Contaminated SRS Soil", WSRC-TR-95-0413, Westinghouse Savannah River Company (in preparation). 


\section{PROJECT EXPENDITURES}

FY 94 Carryover for this TTP was $\$ 783,269$

FY95 Total New Funding was $\$ 736,355$

October 94 Spendout was $\$ 106,636$

November 94 Spendout was $(\$ 63,864)$

December 94 Spendout was $\$ 307,387$

January 95 Spendout was $\$ 169,614$

February 95 Spendout was $\$ 101,869$

March 95 Spendout was $\$ 281,626$

April 95 Spendout was $\$ 215,247$

May 95 Spendout was $\$ 106,153$

June 95 Spendout was $\$ 90,719$

July 95 Spendout was $\$ 108,379$

August 95 Spendout was $\$ 63,261$

September 95 Spendout was $\$<45,068>$

Committed FY95 OE Money Not Spent was $\$ 90,739$

Overspent FY95 CE Money $\$ 13,075$

Total FY 95 Spendout was $\$ 1,441,959$

The billing for the SCUREF contract with the Center, SCUREF Task \#121, is behind schedule. Although, monthly accruals are made to the TTP budget based on University estimates, these accruals are reversed in the following month and actual charges are not billed until an invoice is received. The invoice payment process is at least 4 months behind schedule at this time. Thus, a carryover of the committed funds was necessary. 
ATTACHMENT I - SUMMARY OF PILOT-SCALE ACTIVITIES WITH MERCURY CONTAMINATED SLUDGES 


\title{
Westinghouse Savannah River Company Savannah River Technology Center
}

\author{
WSRC-TR-95-0404 \\ Revision 0 \\ Keywords: sludge, \\ vitrification, glass, \\ mercury \\ September 30,1995
}

\section{SUMMARY OF PILOT-SCALE ACTIVITIES WITH MERCURY CONTAMINATED SIUUDGES}

\author{
Compiled by: Connie A. Cicero \\ Contributing Authors: Nick D. Hudson, Jack R. Zamecnik, \\ Mike E. Smith, Don H. Miller, Jim A. Ritter, \\ Bruce J. Hardy, and Carol M. Jantzen
}

\section{SUMMARY}

Technologies for treatment of low level mixed wastes (LLMW) are currently being investigated by the Mixed Waste Focus Area (MWFA) of the Department of Energy (DOE). The Savannah River Technology Center (SRTC) has been chartered by the MWFA to study vitrification treatment of the wastes through an Office of Technology Development (OTD) Technical Task Plan (TTP). SRTC's efforts have included crucible-scale studies and pilot-scale testing on simulated LLMW sludges, resins, soils, and other solid wastes. Results from the crucible-scale studies have been used as the basis for the pilot-scale demonstrations.

One of the streams to be investigated in fiscal year (FY) 1995 by SRTC was a mercury waste. In FY 1995, SRTC performed crucible-scale studies with mercury contaminated soil. This waste stream was selected because of the large number of DOE sites that have an inventory of contaminated or hazardous soil. More importantly, it was readily available for treatment. Pilot-scale studies were to be completed in FY 1995, but could not be completed due to a reduction in funding. Since the main driver for focusing on a mercury waste stream was to determine how the mercury could be treated, a compilation of pilot-scale tests with mercury sludges performed under the guidance of SRTC is provided in this report. 
The studies summarized in this report include several pilot-scale vitrification demonstrations with simulated radioactive sludges that contained mercury. The pilot-scale studies were performed at the SRTC in the Integrated Defense Waste Processing Facility (DWPF) Melter System (IDMS). The studies involved complete glass and offgas product characterization.

Future pilot-scale studies with mercury streams will likely be performed with mercury contaminated soils, sediments, or sludges because of the need to dispose of this technically challenging waste stream. These pilot-scale studies are likely to focus on new technologies for capturing and converting the mercury to a stable form, since technologies have already been developed for treating most of the residual waste matrices.

\section{BACKGROUND}

Radioactive and mixed waste sludges containing mercury have resulted from the use of mercuric nitrate as a catalyst during nitric acid dissolution of spent fuel rods at the Savannah River Site (SRS) . Treatment methods for disposing of most of these wastes are still being determined, but the high level waste (HLW) mercury containing sludges will be disposed of in the DWPF using vitrification. Since mercury tends to decompose at temperatures much less than the melt temperature of most glasses developed for radioactive wastes, most of the mercury must be removed prior to vitrification. The decomposition of mercury presents two problems, which include environmental release of a toxic substance and release to offgas systems incapable of handling the mercury compounds emitted. When mercury exits in the offgas, it can be present as a complex mixture of halides, oxides, and metals. This mercury mixture would be hard to process, recover, and purify and would also present a corrosion problem to the offgas system. ${ }^{1}$ Therefore, mercury should be removed before the vitrification portion of the process.

\section{IDMS DEMONSTRATIONS}

When vitrifying sludge, the IDMS removes the mercury in the sludge via reduction to mercury metal using formic acid and steam stripping in the Slurry Receipt and Adjustment Tank (SRAT). The mercury is then collected and washed in the Mercury Wastewater Wash Tank (MWWT) before being sent to the Mercury Purification Cell. Any mercury that remains in the melter feed is captured in the offgas system.

Several runs with simulated sludge containing mercury were performed in the IDMS to determine the effects of mercury on the feed preparation process, off-gas chemistry, melting behavior, and glass durability. In all runs, the mercury containing sludge was mixed with the proper additives to make homogeneous glass. The trial names were HG1, HG2, HG3, HM4, PX3, PX4, and PX5. Three of the runs were marginally the same composition (HG1, HG2, and HG3), while the other four were slightly different feed compositions. The specific goal of the three runs with marginally the same composition was to determine the behavior 
of mercury in the whole system. Over 15,000 pounds of glass were poured during these three mercury runs.

For the four other runs, nitric acid was used to neutralize the sludge components (hydroxides and carbonates) as opposed to the formic acid used in the first three runs. Sufficient formic acid in the rest of the melter feed was available to complete the necessary reduction/ oxidation reactions for these four trials. Once again, these reactions were necessary to allow mercury to reduce to its metal state, so it could be steam stripped. 1

\section{MELTER FEED PREPARATION}

The preparation of feed for the runs in the IDMS represented the first large-scale demonstration of mercury removal and recovery at the SRS. The system consists of a SRAT/Slurry Mix Evaporator (SME), a SRAT/SME condenser, a MWWT, and a Waste Water Pump Tank (WWPT). 2 The processing. steps for treating the mercury included:

1) formic acid addition to control glass redox, improve feed rheology, and reduce mercury to the metallic form,

2) refluxing to remove mercury by steam stripping, and then concentrating by boiling,

3) Precipitate Hydrolysis Aqueous (PHA) addition, concentration by boiling and, if necessary, further refluxing to remove mercury.

In each of the designated mercury runs (HG1, HG2, and HG3), the sludge solids to be used were transferred from the Sludge Receipt Tank (SRT) to the IDMS SRAT/SME in preparation for feeding to the melter. The mercury additions were performed separately. In order to convert mercury to the desired form, mercurous nitrate was added to nitric acid and heated to about $60^{\circ} \mathrm{C}$ to convert $\mathrm{Hg}^{1+}$ to $\mathrm{Hg}^{2+}$ and then the mercuric nitrate solution was added to the sludge in the SRAT/SME. 2 Upon addition to the sludge, the mercuric nitrate reacted to form mercuric oxide, which is the anticipated form in SRS radioactive waste.

The melter feed streams for runs HG1, HG2, and HG3 contained 28\%, 28\%, and $26.7 \%$ sludge oxides, respectively. ${ }^{1}$ Analyses of the feed from the three runs is given in Table 1 . As can be seen from the mercury results provided in the table, detection of the mercury in the feed stream was very difficult due to analytical technique. The theoretical elemental mercury concentrations were 1.22 wt: for HG1, 1.19 wt: for HG2, and 1.22 wt: for HG3. For the four additional sludge runs, the sludge oxide loadings were equivalent to those in the mercury runs, and the initial concentration of mercury in the sludge was targeted at 3.2 wto on a dry basis. ${ }^{1}$ 


$\begin{array}{crcc}\text { Table I } & \text { Mercury } & \text { Run Feed Compositions } & \text { (Wt })^{2} \\ \text { exide } & \text { HG1 } & \text { HG2 } & \text { HG3 } \\ \text { Al } & 2.101 & 1.929 & 1.829 \\ \mathrm{~B} & 1.882 & 1.383 & 1.446 \\ \mathrm{Ba} & 0.059 & 0.058 & 0.053 \\ \mathrm{Ca} & 0.619 & 0.609 & 0.580 \\ \mathrm{Cr} & 0.072 & 0.060 & 0.054 \\ \mathrm{Cs} & 0.020 & 0.053 & 0.000 \\ \mathrm{Cu} & 0.155 & 0.087 & 0.106 \\ \mathrm{Fe} & 7.193 & 6.832 & 6.491 \\ \mathrm{Hg} & 0.000 & 0.000 & 0.034 \\ \mathrm{~K} & 1.466 & 0.920 & 1.228 \\ \mathrm{Li} & 1.728 & 1.460 & 1.431 \\ \mathrm{Mg} & 0.728 & 0.581 & 0.583 \\ \mathrm{Mn} & 1.364 & 1.229 & 1.144 \\ \mathrm{Na} & 5.770 & 6.331 & 4.152 \\ \mathrm{Ni} & 0.395 & 0.404 & 0.376 \\ \mathrm{P} & 0.016 & 0.010 & 0.010 \\ \mathrm{~Pb} & 0.141 & 0.094 & 0.057 \\ \mathrm{Si} & 19.948 & 18.339 & 15.328 \\ \mathrm{Sr} & 0.022 & 0.021 & 0.018 \\ \mathrm{Ti} & 0.130 & 0.107 & 0.119 \\ \mathrm{Zn} & 0.277 & 0.153 & 0.161 \\ \mathrm{Zr} & 0.060 & 0.057 & 0.020 \\ & & & \end{array}$

The mercury that was collected in the MWWT was recovered and washed. This mercury was accompanied both by heavy organic material and entrained solids. When the mercury washing was performed on a laboratory scale, problems were encountered because of the presence of the organic material and the entrained solids. The heavy organics and solids were difficult to separate from the mercury and could possibly require several "wash cycles" to remove on a larger scale. It was determined that this removal would only be effective if there was an evenly distributed vigorous air sparge in the mercury pool. 2

\section{OFFGAS SYSTEM OPERATIONS}

In order to contain all of the mercury and organic vapors in the Feed Preparation System, all of the vessels were maintained under a vacuum using the Process Vessel Vent System (PVVS). The PVVS serves every vessel containing mercury and organics in the IDMS except the melter and the Offgas Condensate Tank (OGCT).

Offgas generated from the melter consisted of steam, non-condensable gases from sludge decomposition, air from inleakage and purges, mercury vapor, and particulate matter from entrainment and volatilization. Therefore, the melter offgas system had to maintain a negative pressure in the melter plenum, provide adequate combustion in the melter vapor space, ensure ventilation and treatment of the reaction gases and steams released from the melter, and provide melter pour spout vacuum to initiate and control glass pouring. 
The IDMS melter was purged with air during operation. Offgas exiting the melter passed through a film cooler designed to minimize particulate build up in the offgas line. This film cooler also reduced the offgas from $450-725^{\circ} \mathrm{C}$ to less than $350^{\circ} \mathrm{C}$. After passing through the film cooler, the gas was then scrubbed in the quencher. The quencher was an ejector-venturi scrubber, which reduced the gas temperature below the dew point, disengaged most of the water vapor from the non-condensables, scrubbed entrained glass, and allowed semi-volatile particles (salts) to coalesce. Offgas condensate was used as the motive fluid for the quencher. Any offgas and condensate that left the quencher entered the OGCT where the liquid and vapor disengaged. 3

The offgas from the OGCT was passed through two Steam Atomized Scrubbers (SAS), which removed particulates by combining water with the offgas in a region of turbulent mixing. The droplets of water formed were separated from the vapor in a cyclone separator. The condensate and condensate steam were then returned to the OGCT. The offgas leaving the SAS was passed though a heat exchanger that was designed to separate the condensables from the offgas and remove virtually all of any elemental mercury present. The separated condensables were then returned to the OGCT. Any suspended liquid droplets from the non-condensable gases were removed with an atomized water spray in the High Efficiency Mist Eliminator (HEME).3

After passing through the HEME, the offgas was heated $10^{\circ} \mathrm{C}$ above its dew point to prevent condensation in the High Efficiency Particulate Airfilters (HEPA). The offgas passed through two HEPA filters in parallel, which served as the final treatment step before release to the environment. ${ }^{3}$

The WWPT collecteds the condensate from the MWWT, Formic. Acid Vent Condenser (FAVC), OGCT, PVVS Stack and offgas Stack for treatment on two ion exchange columns. The condensate in the tank was pH adjusted to approximately 12 to precipitate most of the solids so they could be pumped through an ultrafilter unit for removal of the particulates and colloids. 2 The filter water was then passed through two ion exchange columns to remove soluble mercury.

Duolite TM GT-73 ion exchange resin was used to remove mercury from the waste condensate and sump water generated during the process demonstrations. The waste was treated on two $0.40 \mathrm{~m}^{3}$ columns at a flow rate of $0.1 \mathrm{~m}^{3} / \mathrm{min}$. This resin was a polystyrene/divinylbenzene resin with thiol $(\mathrm{S}-\mathrm{H})$ functional groups. On a laboratory scale, it was effective in sorption of $\mathrm{Hg}^{2+}, \mathrm{Hg}_{2}{ }^{2+}$, and $\mathrm{Hg}^{0}$. Leach tests of the resin indicated that it did not lose any $\mathrm{Hg}$ on leaching, and, therefore, was not a secondary waste. The overall capacity in column operation for this waste is about 145 grams $\mathrm{Hg} /$ liter of resin. For the IDMS, it has been found to reduce the $\mathrm{Hg}$ content to below the permitted level of 10 $\mu \mathrm{g} / \mathrm{L}$ for subsequent processing and effluent has been $<5 \mu \mathrm{g} / \mathrm{L} \mathrm{Hg} .4$

Observations for each of the runs pertaining to the offgas system are discussed below. 
HG1

After the feed preparation step, no metallic mercury had accumulated in the mercury sump of the MWWT. Since this was not expected, the condensate line was inspected from the SRAT condenser to the MWWT. The inspection found a large amount ( $>10$ pounds) of elemental mercury trapped in the pipe. The piping connecting these two pieces of equipment was nearly horizontal in some locations, which did not provide enough gravitational flow for the mercury vapors. The mercury was found trapped in the thermowell and at the entrance to the condensate flow measurement device where decreased diameter piping was used. These mercury accumulations caused pressure control problems in the vessel vent system.

HG2

Due to the problems with mercury being trapped in the piping in HGI, slope was added to the line from the SRAT condenser to the MWWT and the piping was replaced with tubing that did not have low points and mercury traps. The modification did not help significantly in allowing the mercury to be collected in the MWWT. Upon inspection of the piping, elemental mercury was found in the line around the flow measurement device again.

During this run, the PVVS offgas entering and leaving the FAVC was sampled for mercury using a modified EPA Method 5 sampling train. The impingers used contained $2 \mathrm{M}$ nitric acid instead of water because nitric acid was believed to capture mercury better. However, hardly any mercury was detected in the solutions.

Also during this run, the feed system was briefly interlocked due to FAVC vapor exit temperatures momentarily exceeding $20^{\circ} \mathrm{C}$. Condensate samples taken during the reflux phase of the operation had small mercury beads present.

\section{$\underline{\mathrm{HG} 3}$}

On account of the continued operation difficulties with the SRAT condenser to MWWT piping, the sample tap and flow measurement device were completely removed from the line. Also, the condensate flow was directed into the MWWT at a slope. These changes allowed the mercury to be easily routed to the MWWT.

The modified EPA Method 5 sampling train was also tested during this run. This time a mixture of approximately $4(\mathrm{w} / \mathrm{v}) \%$ potassium permanganate in approximately $10(\mathrm{w} / \mathrm{v}) \%$ sulfuric acid was used instead of nitric acid. This solution was better for capturing the mercury, but still did not provide optimum results.

\section{OTHER RUNS}

The condensate generated during SRAT/SME cycles for the other four runs contained on average $105 \mathrm{mg} / \mathrm{L} \mathrm{Hg}$, with only one run not being 
consistent. The maximum Hg concentration varied considerably from run to run. The condensate generated during the melter feeding cycle was only measured for three of the runs and contained on average $92 \mathrm{mg} / \mathrm{L}$ soluble $\mathrm{Hg}$. The maximum concentration did not vary nearly as much between these runs. 5

\section{MELTER SYSTEM}

The IDMS melter is a refractory lined, cylindrical tank which operates at glass temperatures of about $1150^{\circ} \mathrm{C}$. The melter has a 24 inch inner diameter. Vitrified material is poured through a drain spout into steel canisters at a rate of about $25 \mathrm{lb} / \mathrm{hr}$. Draining of the melter is controlled by a water driven spout jet that pulis a vacuum on the melter pour spout. The melter is equipped with Inconel resistance heaters in the vapor space to assist in vaporization of the water in the slurry feed and to combust offgases evolved from the slurry.

Before the start of the mercury demonstrations, it was believed that insoluble $\mathrm{Hg}_{2} \mathrm{Cl}_{2}$ (calomel) might form in the offgas line if mercury was carried over into the melter. Formation of insoluble $\mathrm{Hg}_{2} \mathrm{Cl}_{2}$ in the melter offgas system was not observed. Melt rates were not impacted by the addition of $\mathrm{Hg}$ in the feed. The concentration of $\mathrm{Hg}$ in the melter feed and melter offgas system was much lower than predicted, which can be attributed to the more efficient than predicted Hg stripping in the feed preparation system. During the runs, determination of the amounts of $\mathrm{Hg}$ in the feed by analyses was difficult.

Electrical characteristics of the melter electrodes were monitored during feeding and idling during the campaign and were not affected by the operations with mercury feed. During feeding, less power is required for the lower electrodes, while more power is required for the upper electrodes due to the cold cap insulating the upper glass pool from the heat given off from the lid heaters. The total electrode power remained constant. The resistance ratio of the two sets of electrodes was also tracked during the campaign, since this gives an idea about any changes in the glass pool resistivity due to changes in temperature or composition of the glass. The upper electrodes to lower electrodes resistance ratio stayed at about $1.0-1.2$. This ratio is helpful for determining if accumulation of metals is occurring.

\section{MERCURY BALANCE}

As mentioned earlier, mercury is added to the sludge in the form of mercuric nitrate in the SRAT/SME, where it is converted to mercuric oxide. Formic acid is used to reduce the mercuric oxide to elemental mercury in the SRAT/SME product. The mercury in the SRAT/SME is then boiled with the rest of the SRAT/SME product to strip the mercury, which is recovered in the MWWT.

Mercury balances were performed around the SRAT for each of the mercury designated runs using analytical results from samples of the SRAT/SME, the WWPT, and the MWWT. A summary of the results of each of these campaigns is given in Table 2. After the final mercury designated run, 
the bottom of the Melter Feed Tank was visually examined for the presence of mercury, and none was detected.

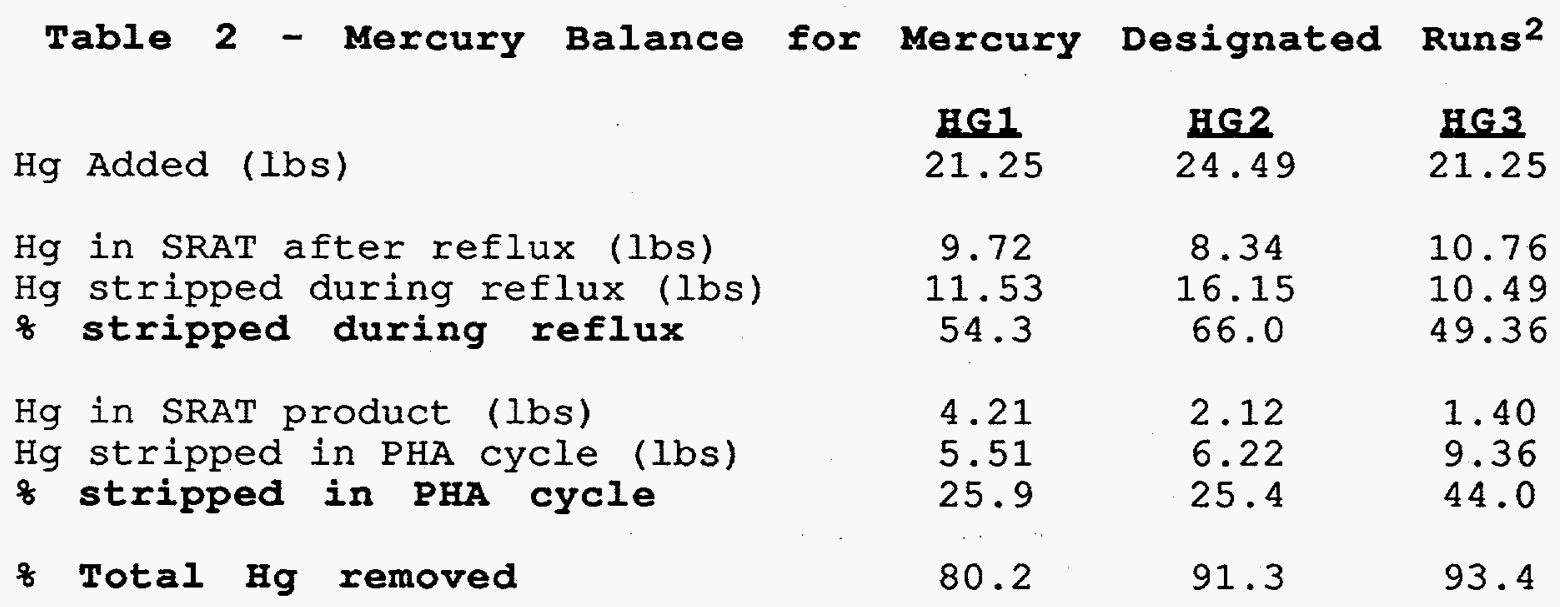

Several samples of the SRAT condensate tank were also taken during the feed preparation steps for HG1. The detected mercury varied from 5,985 to $10,465 \mathrm{ppm} .{ }^{2}$ Both the highest and the lowest concentrations of mercury occurred during the Formic reflux period, with the highest concentration at the beginning and the lowest at the end.

A mercury balance was also performed around the entire offgas system for the three mercury designated runs. Several assumptions about the melter, mercury, and offgas behavior were assumed but will not be elaborated on here. The biggest assumptions were that all of the mercury fed to the melter exits into the offgas, that the concentration of mercury in the OGCT is the same everywhere in the tank, and that the amount of mercury accumulated on the HEME is negligible. Other errors in the balance arose due to problems with analyzing for mercury in the melter feed. Results showed that flame Atomic Absorption (AA) should not be used, and Vapor Gas Analysis (VGA) should be used instead. ${ }^{2}$

Two different types of balances were performed. The first was an unsteady-state analysis, since the concentration of mercury varies with time. ${ }^{2}$ To perform this analyses, balances were performed hourly and samples of the OGCT were taken throughout the day. For the second method, an overall material balance was performed by performing a cumulative summation of the total amounts of mercury. ${ }^{2}$ The results for both methods are shown in Table 3 .

$\begin{array}{ccc}\text { Table } 3 \text { - Melter Offgas Mercury Material Balance for } \\ \text { Mercury Designated Runs } \\ \text { Instantaneous } & \text { Cumulative } \\ \text { Run } & \text { Balance } & \text { Balance } \\ \text { HG1 } & 100.0 & 91.6 \\ \text { HG2 } & 100.2 & 122.5 \\ \text { HG3 } & 99.9 & 99.9\end{array}$


The results from the melter offgas balance indicate that the amount of mercury exiting in the offgas ranged from 0.8 to $3.4 \%$. The results also showed that the mercury concentration depended somewhat on the feed concentration.

Mercury in the scrubber solutions ranged from 16 to $63000 \mu \mathrm{g} / \mathrm{L}$ for the three mercury designated runs. The OGCT condensate contained 0.84 to 1.0 parts of soluble to total mercury. Some of the entrained glass oxides in the condensate appeared to be plated with elemental mercury. The total mercury in the condensate ranged from $1.9-11.9 \mathrm{mg} / \mathrm{L}$, with virtually all of it soluble. No particulate mercury was removed in the filter papers. ${ }^{3}$

\section{CAMPAIGN PERFORMANCE MEASURES}

The mercury Decontamination Factor (DF) across the OGCT, SAS/Offgas Condenser/Mist Eliminator combination and the HEME were determined by measuring the amount of mercury in the offgas for HG2 and HG3. The DF reported is the ratio of the amount of mercury entering the equipment to the amount leaving. Particulate samples were also taken from the offgas on $0.45 \mu \mathrm{m}$ filter paper. Analysis of the papers by X-ray Fluorescence and electron microscopy showed no evidence of mercury.

The mercury DF's for both the OGCT and the HEME were larger than predicted.2 The design basis for the HEME assumed that most of the mercury entering the HEME was elemental mercury vapor and that it would not be removed, but some mercury was removed. Since the HEME was wetted by a constant stream of water, the $\mathrm{HgO}$ and $\mathrm{HgCl}_{2}$ in the offgas were scrubbed by the HEME. ${ }^{3}$ The DF for the Steam Atomized Scrubber (SAS) /Offgas Condenser/Mist Eliminator was smaller than predicted.

Table 4 shows the DFs for runs HG2 and HG3.

$\begin{array}{ccc}\text { Table 4 - Mercury } & \text { Decontamination } & \text { Factors } \\ \text { Equipment } & \text { HG2 } & \text { HG3 } \\ \text { OGCT } & 8.28 & 3.32 \\ \text { SAS/OG Cond/ME } & 4.86 & 1.60 \\ \text { HEME } & 1.84 & 5.58 \\ \text { Overall } & 74.2 & 29.7\end{array}$

The concentrations of mercury in the melter offgas system for the mercury designated campaigns are given in Table 5 . Concentrations were lower than predicted due to more efficient than predicted steam stripping efficiency.

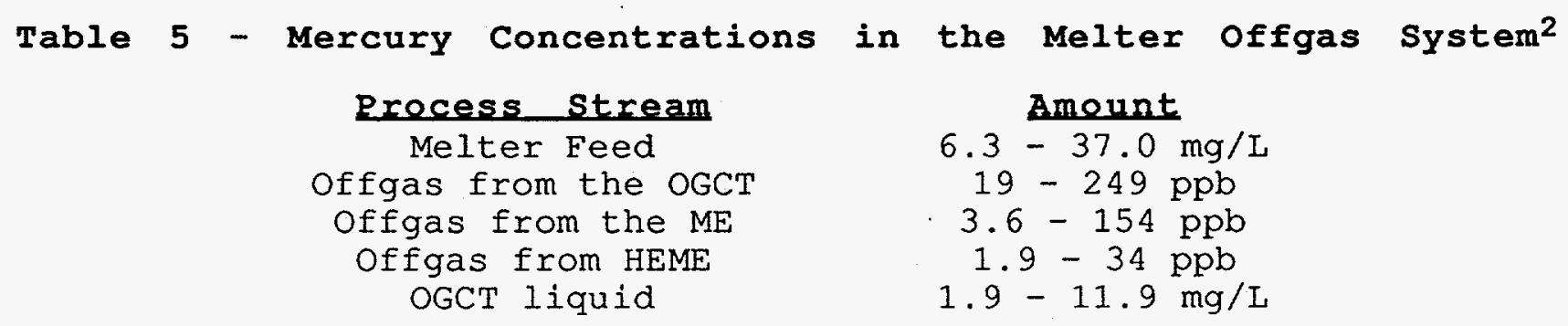


Calculations of the steam stripping efficiency for the demonstrations were also completed. This was defined by the following equation: (250 lb steam/lb Hg stripped)

$\therefore$ Eff. = (total lb steam/total ib Hg stripped) $\times 100$

where the numerator is the theoretical steam required based on the vapor pressure of mercury at $100^{\circ} \mathrm{C} .^{2}$ Results from the three mercury designated runs indicated that the amount of steam required per pound of mercury stripped were higher than predicted. The calculated efficiencies for the overall feeding process were very low because of the low efficiencies experienced during the PHA cycle. The overall efficiencies were 18\% for HG1, $7 \%$ for $\mathrm{HG} 2$, and $21 \%$ for $\mathrm{HG} 3$. For the other runs, steam efficiencies were good, exceeding the 33\% design basis. 1

For HM4, the efficiency peaked at about 40\% and declined to 25-30\%, which is below the design basis of 33\%. The efficiency for PX3 and PX4 sharply increased with the addition of $\mathrm{PHA}$, and later declined. The peak efficiency was very great and only declined to the design point of $33 \%$ by the end of SME operation. ${ }^{1}$

A design final concentration of mercury in the sludge was determined to be 0.45 wt $\frac{0}{6}$ based on available data. ${ }^{2}$ For the three mercury designated runs, this design concentration was exceeded. The results were 0.24 wt: for HG1, 0.11 wto for HG2, and 0.08 wto for HG3.2 Exceeding this endpoint is usually considered inefficient processing. For the other runs, the design basis mercury endpoint was attained without increasing the SRAT cycle time. More than $80 \%$ of the initial mercury was removed from the feed in each of the runs. 1

For the HM4 run, the mercury concentration stayed constant until the start of the PHA addition, then it started to decline sharply until approximately $75 \%$ had been removed. No steam stripping was evident during the SME cycle. After completion of the SRAT processing, the mercury concentration was 0.59 wt: For $\mathrm{PX} 3$ and $\mathrm{PX} 4$, mercury content decreased throughout the PHA addition/concentration cycle. At the end of processing, approximately $82 \%$ had been removed in $\mathrm{PX} 3,70-80 \%$ had been removed in PX4, and $90 \%$ had been removed in PX5. The mercury concentration was 0.54 wt: for $\mathrm{PX} 3,0.49$ wt\% for PX4, and 0.03 wt: for $\mathrm{PX} 5$. Additional steam stripping occurred in the SME cycle for both $\mathrm{PX} 3$ and $\mathrm{PX} 4$. The increased removal in $\mathrm{PX} 5$ was most likely due to the result of maintaining a vigorous boil with high steam flows during the PHA addition. 1

The DF for the melter was considered unity since mercury is not vitrified into the glass.

\section{GLASS PRODUCT QUALITY}

Glass samples were taken at the beginning, middle, and end of each run of the campaign. The durability of the glasses from each run was determined using the product Consistency Test (PCT). ${ }^{6}$ The PCT is a 7day glass leach test that is performed at $90^{\circ} \mathrm{C}$. The test is performed 
on 100-200 mesh glass specimens using ASTM Type I. Water as the leach solution.

PCT results for durability indicated that the glasses were more durable than the DWPF Environmental Assessment (EA) glass ${ }^{7}$. A decrease in durability was noticed for the glasses produced after the addition of $\mathrm{NaOH}$ as a trim chemical in $\mathrm{HG} 2$, but this was not a direct result of mercury additions. 8 The measured durabilities were comparable to previously produced glasses without mercury additions.

\section{CONCLUSIONS}

A brief summary of the relevant findings of the SRTC campaigns discussed in this paper follows:

- Mercury was successfully removed from the feed to the melter during the steam stripping process in the SRAT/SME.

- In order for mercury washing to be successful, an evenly distributed vigorous air sparge should be used in the MWWT because of the heavy organics and solids also present.

- Removal of the sample trap and flow measurement device from the transfer line of the SRAT condenser to the MWWT was necessary to avoid accumulation of mercury in the line. Adding slope to the line also helped with this problem.

- Melt rates and melter operating conditions were not impacted by the addition of mercury into the feed stream.

- It did not appear that any mercury exited in the melter offgas line, due to the absence of $\mathrm{Hg}_{2} \mathrm{Cl}_{2}$ in the line.

- Mercury balances were successfully performed around the SRAT and melter offgas system.

- Mercury DF's for the OGCT and HEME were larger than predicted, while they were smaller than predicted for the SAS/Offgas Condenser/Mist Eliminator.

- Calculated steam stripping efficiencies for the mercury designated runs were lower than expected (18\% for HG1, $7 \%$ for HG2, and 21\% for HG3), but exceeded the design basis (33\%) for the other four runs.

The design final concentration of mercury in the feed 10.45 wt $\%$ ) was exceeded for HG1 (0.24 wt \%), HG2 (0.11 wt\%), HG3 $(0.08 \mathrm{wt} \%)$, and PX5 (0.03 wt\%). The value for PX5 was far below the design basis and was most likely the result of an increased steam flow, an increased flux, and continuous addition of PHA, since increased SRAT cycle times were not required. 
Durability of glasses as measured by the PCT was not affected by the addition of mercury. All glasses performed better than the EA glass.

\section{ACKNOWLEDGEMENTS}

Funding for the summation part of this research and development work was provided by the Department of Energy - Office of Technology Development under the auspices of the Mixed Waste Focus Area and Technical Task Plan SR1-3-20-04. Funding for the studies at the SRTC was provided by the Department of Energy under contract DE-AC09-89SR18035.

\section{REFERENCES}

1. N.D. Hutson, "An Evaluation of Mercury Removal in the IDMS Using the Nitric Acid Flowsheet", WSRC-TR-92-0492, Westinghouse Savannah River Company (October 22, 1992).

2. N.D. Hutson, J.R. Zamecnik, D.H. Miller, M.E. Smith, and J.A. Ritter, "Integrated DWPF Melter System (IDMS) Campaign Report- Mercury Operation", WSRC-TR-91-0363, Westinghouse Savannah River Company, Aiken, SC (May 22, 1991).

3. J.R. Zamecnik, "Measurement of Cesium and Mercury Emissions from the vitrification of Simulated High Level Radioactive Waste", WSRC-MS-92-268, Westinghouse Savannah River Company (1992).

4. A.B. Osteen and J.P. Bibler, "Treatment of Radioactive Laboratory Waste for Mercury Removal", Water, Air, and Soil Pollution, Volume 57, Kluwer Academic Publishers (Netherlands), pp. 63-74 (1991).

5. J.A. Ritter, "Mercury Levels in IDMS Condensate", SRTC-ISE-930022, Westinghouse Savannah River Company, Aiken, SC (April 21, 1993).

6. C.M. Jantzen, N.E. Bibler, D.C. Beam, W.G. Ramsey, and B.J. Waters, "Nuclear Waste Product Consistency Test (PCT) - Version 5.0" WSRC-TR-90-539, Rev. 2, Westinghouse Savannah River Company, Aiken, SC (January 1992).

7. C.M. Jantzen, N.E. Bibler, D.C. Beam, C.L. Crawford, and M.A. Pickett, "Characterization of the Defense Waste Processing Facility (DWPE) Environmental Assessment (EA) Glass standard Reference Material", WSRC-TR-92-346, Westinghouse Savannah River Company, Aiken, SC (June 1, 1.993).

8. C.M. Jantzen, "Durability of Glasses from the Hg-Doped Integrated DWFP Melter System (IDMS) Campaign", WSRC-RP-91-371, Westinghouse Savannah River Company, Aiken, SC (August 30, 1992) 
ATTACHMENT II - SUMMARY OF PILOT-SCALE ACTIVITIES WITH RESORCINOL ION-EXCHANGE RESIN 


\title{
W Westinghouse Savannah River Company Savannah River Technology Center
}

\author{
WSRC-TR-95-0403 \\ Revision 0 \\ Keywords: low \\ level mixed wastes, \\ vitrification, resin \\ September 30, 1995
}

\section{SUMNARY OF PIIOT-SCAIE ACTIYITIES HTTH RESORCINOI ION FXCHANGE RESTN}

\author{
Compiled by: Connie A. Cicero \\ Contributing Authors: Dennis F. Bickford, \\ Thomas N. Sargent, Mary K. Andrews, Jane P. Bibler, \\ Ned E. Bibler, and Carol M. Jantzen
}

\section{SUMMARY}

The Mixed Waste Focus Area (MWFA) of the Department of Energy (DOE) is currently investigating vitrification technology for treatment of low level mixed wastes (LLMW). They have chartered the Savannah River Technology Center (SRTC) to study vitrification of the wastes through an office of Technology Development (OTD) Technical Task Plan (TTP). SRTC's efforts have included crucible-scale studies and pilot scale testing on simulated LLMW sludges, resins, soils, and other solid wastes. Results from the crucible-scale studies have been used as the basis for the pilot-scale demonstrations.

As part of the fiscal year (FY) 1995 activities, SRTC performed crucible-scale studies with organic resins. This waste stream was selected because of the large number of DOE sites, as well as commercial industries, that use resins for treatment of liquid wastes. Pilot-scale studies were to be completed in FY 1995, but could not be due to a reduction in funding. Instead, a compilation of pilot-scale tests with organic resins performed under the guidance of SRTC was provided in this report.

The studies which will be discussed used a resorcinol-formaldehyde resin loaded with non-radioactive cesium, which was fed with simulated wastewater treatment sludge feed. The first study was performed at the 
SRTC in the mini-melter, 1/100th scale of the Defense Waste Processing Facility (DWPE) melter, and also involved limited crucible-scale studies to determine the resin loading obtainable. The other study was performed at the DOE/Industrial Center for Vitrification Research (Center) and involved both crucible and pilot-scale testing in the StirMelter ${ }^{\circledR}$ stirred-melter.

Both studies were successful in vitrifying the resin in simulated radioactive sludge and glass additive feeds. The tests in the minimelter could only retain a maximum of 5 grams of resin/100 grams of glass produced, which was nearly identical to the tests at the Center which were able to load 4.91 grams of resin/100 grams of glass produced. The slightly lower resin loading in the Center studies was not expected since it was believed that the Stir-Melter could more easily incorporate the resin into the glass matrix because of increased air/glass contact and active use of an air sparger.

Future pilot-scale studies will likely be performed with organic resins because of the need to dispose of this growing waste stream. These studies are likely to focus on new technologies that are being developed for pre-treating the resin or on optimization of the glass formula used to entrain the resin, where both should result in higher waste loadings obtainable.

\section{BACKGROUND}

Spent ion exchange resin is a result of many different waste treatment processes. It is used by DOE and commercial facilities for removing unwanted contaminants in liquid or aqueous streams. These contaminants can be either radioactive or hazardous in nature. Thus, the spent resin then becomes either a High Level Waste (HLW), LLMW, Low Level Waste (LLW), or hazardous waste depending on what contaminants it has removed from the waste streams. In some cases, the resins themselves are considered hazardous because of the organic content.

Ion exchange resins are also used in the defense and commercial power reactors to remove anions and cations, particularly low levels of fission products such as $\mathrm{Cs}$ and $\mathrm{Sr}$. Commercial reactors typically use resins with sulfonated groups, and ashes or residues resulting from such resins are usually high in sulfur.

Resorcinol-formaldehyde resin has been proposed for treatment of radioactive wastewater treatment sludges at the Savannah River Site (SRS). This resin was specifically developed for treatment of the supernate from the HLW tanks by J.P. Bibler of SRTC ${ }^{1}$ and it has a Cs capacity that is four times greater than the best commercial resin. ${ }^{2}$ The supernate portion of radioactive wastewater treatment sludges usually contains most of the $\mathrm{Cs}$ and thus the radioactivity, so it usually has to be treated to reduce the radioactivity before final treatment. At present, HLW tank supernate at SRS is treated using sodium tetraphenylborate during a precipitation process. This stream is then treated to decrease the organic content by incorporating the hydrolysis of the sodium tetraphenylborate with formic acid to yield 
benzene which is removed through steam distillation. 3 The resulting precipitate hydrolysis aqueous (PHA) product is then sent to the DWPF to be mixed with the sludge portion of the HLW tanks and glass frit. This process has several disadvantages including the presence of large amounts of sodium, potassium, and titanium that are fed to the melter, and, more importantly, regulatory and safety concerns of handling the benzene waste stream.

By using the resorcinol resin to remove the Cs for the SRS HLW process and in other processes, the need for additional benzene destruction equipment is eliminated and the feed can be directly fed into the treatment system without any additional treatment requirements. If vitrification is used, a lower amount of alkali metals is fed to the melter, which increases the reliability of the glass making process because of the affect alkalis have on durability. A final advantage, from a glass processing standpoint, would be the reduction in the amount of titanium fed to the melter which would reduce the potential for the. glass to devitrify and for spinels to form in the melter. Another advantage of the resorcinol resin over other resins is that it does not contain sulfur, so when it is destroyed, sulfate salts are not produced as they might be with commercial resins.

The biggest disadvantages of using the resin treatment process at the SRS were not safety or glass quality related. They included the cost and schedule impact for establishing the treatment facilities, and the need for further details on engineering scale-up.

In order for the supernate resin treatment and vitrification destruction process to be considered plausible, demonstrations of the capability to remove the $\mathrm{Cs}$ and vitrify the resulting resin product had to be performed. J.P. Bibler was responsible for proving that the Cs was actually removed from the supernate stream and for providing nonradioactive Cs loaded resorcinol resin for crucible-scale vitrification studies. The typical composition of the dried resin after Cs removal from a simulated HLW supernate is given in Table 1.4

$\begin{array}{cc}\text { Table } 1 \text { - Non-Radioactive Cs-Loaded Resin Composition } \\ \text { Element } & \text { Wt8 } \\ \text { C } & 35.5 \\ \mathrm{Na} & 7.0 \\ \mathrm{CS} & 0.95 \\ \mathrm{O} & 45.5 \\ \mathrm{H} & 5.8 \\ \mathrm{~K} & 0.07\end{array}$

In the commercial nuclear power sector, ion-exchange resins generated as wastes require processing prior to disposal. Several volume-reduction methods have been used in the past, but none have offered complete stabilization or large reduction results when a large volume of resin waste is considered. Current practices for storage or disposal are expensive, so if it can be proven that vitrification could successfully incorporate the radioactive components into the glass matrix, destroy 
the organics, and produce an appreciable volume reduction, much benefit would be gained by the commercial nuclear power sector.

\section{RESIN STUDIES AT SRTC}

Once the viability of using the resorcinol resin for removing Cs from the supernate was proven, the concept of vitrifying the resin had to be demonstrated. Samples of the non-radioactive Cs loaded resin were obtained for the studies. Samples of simulated radioactive wastewater treatment sludge and a frit glass additive were also obtained, since these two streams would be fed with the resin into the melter for vitrification.

\section{Crucible-scale}

Crucible-scale vitrification studies with the non-radioactive Cs loaded, resin were performed by C.M. Jantzen of the SRTC. The main goal of these studies was to determine how the resin would affect the redox of the glass melt. Several trials were performed using varying amounts of resin and nitrate as an oxidizing agent. In these studies, the Cs was intimately mixed with a simulated radioactive sludge and glass frit. The crucibles of the feed were dried and then melted for 4 hours at $1150^{\circ} \mathrm{C}$. After air quenching the samples, the glasses were analyzed for $\mathrm{Fe}^{2+} / \Sigma \mathrm{Fe}$ ratio.

The compositions of the simulated radioactive sludge and glass frits used in the studies are given in Table 2.4 The simulated radioactive sludge composition is shown on the basis of total solids after drying and is typical of sludges found at the SRS. When the sludge is in the melter feed form, it would also contain soluble formates, nitrates, and nitrites. The frit used in these experiments was Frit 165, which was developed for HLW sludge processing. These two streams were nominally mixed at 28 wt\% sludge oxides and 72 wto frit oxides.

\begin{tabular}{ccc} 
Table $2-$ Crucible-Scale Feed & Compositions \\
Oxide & Sludge & Frit 165 \\
\hline $\mathrm{Al}_{2} \mathrm{O}_{3}$ & 6.61 & 0.3 \\
$\mathrm{~B}_{2} \mathrm{O}_{3}$ & 2.06 & 10.5 \\
$\mathrm{CaO}$ & 2.38 & 0.23 \\
$\mathrm{Fe}_{2} \mathrm{O}_{3}$ & 17.30 & 0.04 \\
$\mathrm{~K}_{2} \mathrm{O}$ & $\mathrm{N} / \mathrm{A}$ & 1.0 \\
$\mathrm{Li}_{2} \mathrm{O}$ & 1.14 & 6.9 \\
$\mathrm{MgO}$ & 0.50 & 0.64 \\
$\mathrm{MnO}_{2}$ & 4.43 & $\mathrm{~N} / \mathrm{A}$ \\
$\mathrm{Na}_{2} \mathrm{O}$ & 9.57 & 11.0 \\
$\mathrm{PbO}_{\mathrm{SiO}}$ & $\mathrm{N} / \mathrm{A}$ & 0.2 \\
$\mathrm{TiO}_{2}$ & 10.91 & 65.0 \\
$\mathrm{ZnO}_{\mathrm{ZrO}}$ & $\mathrm{N} / \mathrm{A}$ & 2.0 \\
$\mathrm{Total}$ & 0.25 & $\mathrm{~N} / \mathrm{A}$ \\
& $\underline{\mathrm{N} / \mathrm{A}}$ & 2.4 \\
& 55.15 & 100.21
\end{tabular}


Results of the studies showed that as the resin loading increased, so did the $\mathrm{Ee}^{2+/} \mathrm{EFe}$ ratio. Another item noted during the testing was that the presence of nitrates tended to decrease the $\mathrm{Fe}^{2+/ \Sigma \mathrm{Fe}}$ ratio.

The maximum loading obtained in these studies was 5 grams of resin per 100 grams of glass produced. The limiting glass property constraint was the glass redox $\left(\mathrm{Fe}^{2+} / \Sigma \mathrm{Fe}\right.$ ratio), since ratios below 0.33 are suggested to limit reduction of nickel and other metals. If this upper limit were exceeded, a strong chance of shorting a joule-heated melter exists.5 The maximum loading suggested still provided an acceptable glass redox.

\section{Pilot-Scale}

For the pilot-scale demonstrations at SRTC, runs were made in the $1 / 100$ th scale joule heated melter. This melter is a ceramic-lined melter that nominally holds $18 \mathrm{~kg}$ of glass in the melt chamber. It normally operates at $1150^{\circ} \mathrm{C}$. Glass is poured from the melter into one liter stainless steel beakers. A small offgas system is also attached to the melter which collects the condensate from the water fed to the melter, as well as entrained particulates.

Three different runs were made for the tests with resorcinol resin, with each run using a total of $120 \mathrm{~kg}$ of feed and producing $30 \mathrm{~kg}$ of glass. In all runs, simulated radioactive sludge and glass frit were used as the feed, at about 42 wt: solids. The composition of the feeds was the same as that given in Table 2 above. The first run was a baseline run and did not contain any resin, while the second and third runs contained resin intermixed in the feed. For the first two runs, the melter was fed for three 16-hour intervals and one 8-hour interval over three days and idled for 8 hours each of the first two days. In the final run, the melter was fed continuously for 53 hours (2.2 days). The intent of the runs was to determine what effect the resin had on the glass product (redox and durability) and on the melter and offgas performance.

In the first and second runs, glass samples were taken once steady-state conditions were obtained, which corresponded to the seventh can collected. For the third run, the glass samples were taken from the third can, which also corresponded to steady state conditions. Since the feed from the second run was still in the melter and was the same composition as the third feed, steady-state was obtained sooner. The composition of the glass samples from each run are given in Table 3.4 The composition for each run was fairly similar, as expected, since they were all the same feed composition. 


\begin{tabular}{cccc} 
Table $3-$ SRTC Resin & $\begin{array}{c}\text { Glass Compositions } \\
\text { (Wt8) }\end{array}$ \\
Oxide & Run 1 & Run 2 & Run 3 \\
\hline $\mathrm{Al}_{2} \mathrm{O}_{3}$ & 4.04 & 3.62 & 3.77 \\
$\mathrm{~B}_{2} \mathrm{O}_{3}$ & 7.32 & 7.16 & 6.62 \\
$\mathrm{CaO}$ & 0.92 & 0.81 & 0.87 \\
$\mathrm{Cr}_{2} \mathrm{O}_{3}$ & 0.37 & 0.38 & 0.33 \\
$\mathrm{Fe}_{2} \mathrm{O}_{3}$ & 8.53 & 6.09 & 6.64 \\
$\mathrm{~K}_{2} \mathrm{O}$ & 1.21 & 0.96 & 1.00 \\
$\mathrm{Li}_{2} \mathrm{O}$ & 4.51 & 4.65 & 4.45 \\
$\mathrm{MgO}$ & 0.77 & 0.74 & 0.73 \\
$\mathrm{MnO}$ & 1.48 & 1.43 & 1.56 \\
$\mathrm{Na}_{2} \mathrm{O}$ & 11.69 & 12.13 & 11.91 \\
$\mathrm{NiO}^{\mathrm{SiO}}$ & 0.69 & 0.58 & 0.55 \\
$\mathrm{TiO}_{2}$ & 50.20 & 50.10 & 49.60 \\
$\mathrm{ZnO}^{\mathrm{ZrO}_{2}}$ & 1.06 & 1.06 & 1.01 \\
& 0.17 & 0.18 & 0.22 \\
& 1.26 & 1.36 & 1.31
\end{tabular}

Since the glass redox is such an important criteria for processing organics in a melter, the $\mathrm{Fe}^{2+} / \Sigma \mathrm{Fe}$ ratio was measured on several glasses from each run using colorimetric analysis. The $\mathrm{Fe}^{2+} / \sum \mathrm{Fe}$ ratio results ${ }^{4}$ are given in Table 4, with the first number of the ID indicating the run number and the second number indicating the can number. The $\mathrm{Fe}^{2+} / \Sigma \mathrm{Fe}$ ratios varied from run to run and from can to can as expected because of the introduction of the resin into the glass melt. When resin was present, the ratio increased and the glass was more reduced. The intermittent resin run had the lower ratios, which can be attributed to the allowance of $\mathrm{O}_{2}$ to diffuse back into the melt during the 8-hour idling period. In some cases, the redox ratio was greater than the recommended $0.33,5$ but no evidence of shorting was observed in the melter.

$\begin{array}{cc}\text { Table } 4 \text { - SRTC Resin } \mathbf{F e}^{2+} / \text { VFe Ratios } \\ \text { Glass ID } & \begin{array}{c}\text { Batio } \\ 1-01\end{array} \\ 1-03 & 0.02 \\ 1-07 & 0.09 \\ 1-10 & 0.12 \\ 1-12 & 0.12 \\ 2-01 & 0.07 \\ 2-03 & 0.28 \\ 2-07 & 0.34 \\ 2-10 & 0.35 \\ 2-12 & 0.33 \\ 3-01 & 0.14 \\ 3-03 & 0.34 \\ 3-06 & 0.42 \\ 3-09 & 0.40 \\ 3-12 & 0.44\end{array}$


The Product Consistency Test $(\mathrm{PCT})^{6}$ was performed on the glass samples to determine how the glass performance compared to the DWPF Environmental Assessment (EA) performance criteria ${ }^{7}$ for durability, since these are the only PCT criteria currently established. The PCT is a 7-day crushed glass leach test, which is performed at $90^{\circ} \mathrm{C}$ using deionized water. The resulting leach solution is analyzed for elemental concentrations to determine the durability of the glass. The pH of the test leachate is also measured since it provides a secondary indication of the glass durability. The data for the SRTC resorcinol resin glasses 4 is given in Table 5. The data shows that the $B$ release and measured $\mathrm{pH}$ increased or glass durability decreased as the $\mathrm{Fe}^{2+/ \Sigma \mathrm{Fe}}$ ratio increased or as more resin was incorporated in the glass matrix. Similar trends were shown for the $\mathrm{Na}$, $\mathrm{Li}$, and $\mathrm{Si}$ releases, but they were not reported. The reason for the poorer durability of the reduced glasses can be attributed to the role of $\mathrm{Fe}^{2+}$ as network modifier instead of a network former. $\mathrm{Fe}^{3+}$ is a network former. Even though the $\mathrm{B}$ releases and measured pHs were higher for the more reduced glass, they were still well below the EA glass performance criteria ${ }^{7}$.

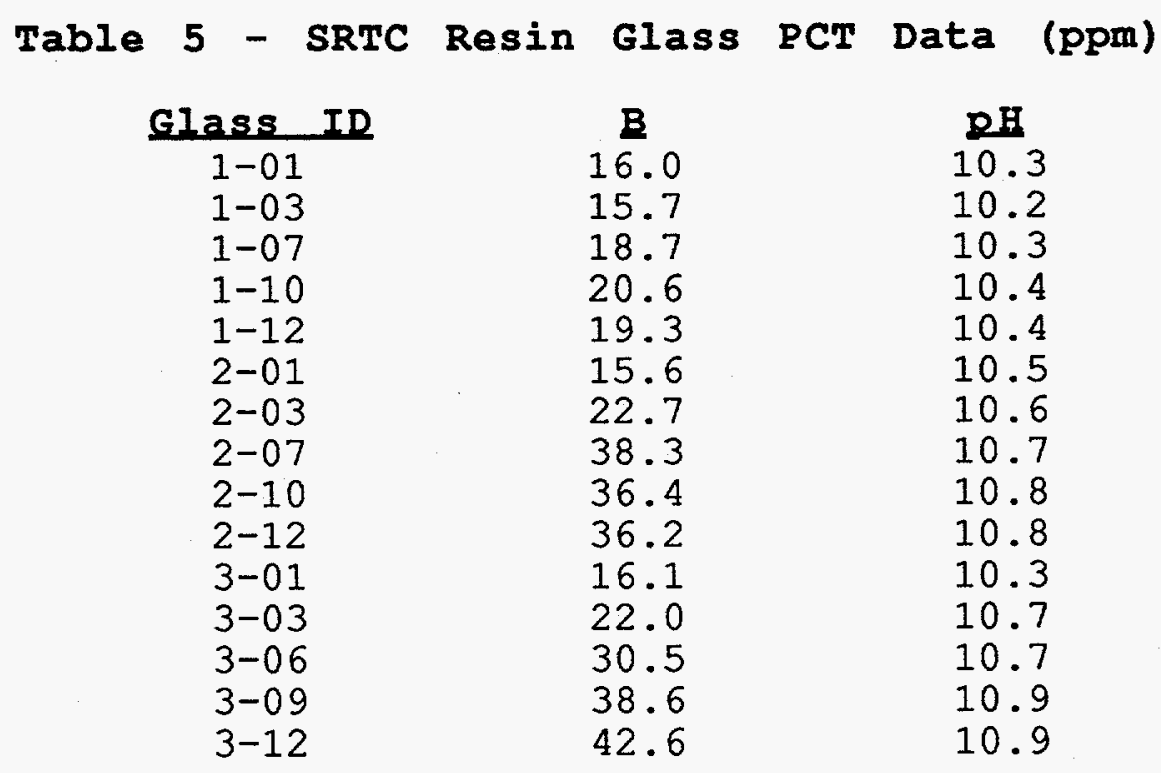

No changes in the melter operating conditions were experienced for the melter when the resin was processed. No effect on the amount of current needed to heat the melter was seen, which suggests that the resin did not produce any conductive species in the melt capable of shorting out the melter. Also, pluggages in the melter feed tube and the offgas system were not observed. Finally, the viscosity of the glass melt did not seem to be affected by the resin addition. 4

The results from the pilot-scale studies at SRTC indicated that vitrification of resorcinol resin was possible when fed to the melter with simulated radioactive sludge and glass frit feed. The maximum loading obtained in the melter was 5 grams of resin/100 grams of glass produced. Higher waste loadings could have been possible, but were not tested due to the redox limits for the melter. Complete details of the SRTC studies can be found in Attachment $I$. 


\section{RESIN STUDIES AT THE CENTER}

As part of a graduate student's (T.N. Sargent) thesis project, vitrification of resorcinol resin was investigated at the center. The thesis involved four different parts, each of which was needed for the final pilot-scale demonstration. The four parts of this project included: crucible studies to determine the reducing potential of the resin and the extent of oxygen consuming reactions; establishment of nominal melter operation parameter values; oxygen transfer tests to approximate the extent of oxygen transfer into the molten glass using an impeller and a combination of the impeller and an external oxygen transfer system; and a pilot-scale test using the stirred melter. 8 The crucible-scale, oxygen transfer tests, and pilot-scale studies will be summarized in this paper. Complete details of this study can be found in the graduate students thesis, given as Attachment II.

The crucible-scale experiments investigated the effects of organic compound additions on oxidation/reduction shifts and cesium retention for the glass wasteform. By performing the oxygen transfer tests, optimum conditions for operating the melter with resin were determined. The pilot-scale tests, on the other hand, were used to approximate a cesium mass balance around the melter including the feed, exit glass, and offgas streams. A major goal of the pilot-scale efforts was to try to eliminate the crust that forms on top of the melt when resin is fed with the glass feed and to try for more oxidizing conditions in the melter. Both of these would theoretically help lower the cesium volatility.

\section{Crucible studies}

For the crucible studies, reagent grade chemicals were used with a composition similar to the feed used in the SRTC studies. The studies involved filling high purity alumina crucibles with identical amounts of glass forming chemicals. These chemicals were frit, anhydrous borax, ferric oxide, and sodium carbonate. Parameters that were varied included the amount of organic material, the presence of water, and the inclusion of a sealed lid on the crucible. All of the samples were placed in a pre-heated furnace at $600^{\circ} \mathrm{C}$, and then the furnace temperature was increased to $1100^{\circ} \mathrm{C}$. The samples were melted at $1100^{\circ} \mathrm{C}$ for three hours and them removed and air quenched. The sealed samples remained sealed during quenching.

The glasses fabricated for the crucible studies were analyzed for $\mathrm{Fe}^{2+} / \Sigma \mathrm{Fe}$ ratio to determine the redox state and for $\mathrm{Cs}$ content to determine the retention ability. Measured values varied from $0.022-$ 0.833 for the $\mathrm{Fe}^{2+/ \Sigma \mathrm{Fe}}$ ratio. The redox values were used to correlate the redox results with the parameters which could affect the final redox state of the glass. The following equations were developed: based on the entire set of crucibles

$$
\begin{gathered}
\mathrm{Fe}^{2+} / \Sigma \mathrm{Fe}=(1.28 * \mathrm{C})+(0.343 * \mathrm{R})+(0.0292 * \mathrm{~W})+(0.159 * \mathrm{~L}) \quad \mathrm{R}^{2}=0.92, \\
\text { and for the sealed crucibles only } \\
\mathrm{Fe}^{2+/ \Sigma \mathrm{Fe}}=(2.10 * \mathrm{C})+(0.530 * \mathrm{R})+(0.0255 * \mathrm{~W}) \quad \mathrm{R}^{2}=0.96,
\end{gathered}
$$


where $C$ is the grams of carbon, $R$ is the grams of resin, $W$ is the $\mathrm{mL}$ of water, and $L$ is the type of environment ( 1 for a lid, 0 for no lid).8 It was found that the presence of water hindered the re-oxidation of the glass rather than assisting as an oxygen donor.

The results of the crucible studies indicated that, based solely on the redox ratio limit of $0.33^{7}, 1.26$ grams of resin could be added to 100 grams of glass in a sealed environment. However, if the crucible was not sealed, 4.91 grams of resin could be added per 100 grams of glass.8 These limits were slightly less than those observed in the SRTC crucible studies ${ }^{4}$.

For all of the glasses fabricated, including those made with carbon, the amount of $\mathrm{Cs}_{2} \mathrm{O}$ measured in the glasses varied from $0.11-0.46$ wt: versus a predicted $\mathrm{Cs}_{2} \mathrm{O}$ content of $0.16-0.52$ wt\%. This corresponded to a Cs retention range of 59.38 - $97.57 \%$. The average cesium retention in the crucible melts with resin, as opposed to carbon, was $88.6 \%$ with a standard deviation of $6.6 \% .8$ The results indicated that the final redox ratio and mass of reducing agent did not seem to influence the Cs retention.

\section{Oxygen Transfer Tests}

The oxygen transfer tests were performed to determine the extent of oxygen transfer into the molten glass using an impeller and a combination of the impeller and an external oxygen transfer system. 8 Two of the oxygen transfer tests were batch type experiments using no feed slurry. In these tests, a known amount of glass was placed in the melter, and the impeller agitated the molten glass for several hours to assure equilibrium with the atmosphere. Once at equilibrium, a measured quantity of elemental carbon was added to the melt to increase the $\mathrm{Fe}^{2+/ \Sigma \mathrm{Fe}}$ ratio. After complete reaction of the carbon, glass samples were taken from the melt surface and operational conditions were initiated. Samples were taken periodically for the next several hours. The only difference in the batch tests was that one did not have any water fed to the melter, while the other was fed at a rate of 35-40 $\mathrm{mL} / \mathrm{min} .^{8}$

The second type of oxygen transfer test used continuous slurry flow at a rate of $50 \mathrm{~mL} / \mathrm{min}$ and an exit glass stream was established. Oxygen was also fed to the melter during this test at a rate of $1000 \mathrm{~mL} / \mathrm{min}$. Once successful operation was achieved, non Cs loaded resin was batch fed to the melter in 30 to 100 gram portions to increase the $\mathrm{Fe}^{2+} / \mathrm{EFe}$ ratio. A total of 300 grams of resin were fed. 8 During this run, the redox state was monitored by periodically sampling the molten glass for colorimetric redox analyses and by using the on-line redox probe. The molten glass samples were taken both from the melt surface and the exit stream. The redox probe was made of a hollow ceramic probe with a zirconium oxide pellet at the tip. This probe contained platinum and rhodium wires which allowed the redox and temperature to be measured. This allowed for a rough correlation between redox probe readings and actual measured redox ratios. 
Equations for determining the amount of recovery time it takes for the melter to return to normal operating conditions were derived for both types of oxygen transfer tests. In the first batch mode tests, the approximate oxygen transfer rate was 0.00230 moles $\mathrm{O}_{2}$ per minute with the impeller running. This correlated to an accommodation resin flow rate of 0.1104 grams resin/min. For the second batch mode test where water was added to the feed, the oxygen transfer rate was 0.00153 moles $\mathrm{O}_{2} / \mathrm{min}$ with an equivalent flow rate of resin as 0.0734 grams resin $/ \mathrm{min} .8$ Since the only difference between the two batch tests was the presence of water, it appeared that the presence of water seemed to hinder the re-oxidation of the melt. In the slurry feeding tests, a total of 300 grams of resin was added to the melt. The amount of time it took for the melt to re-oxidize was recorded and during the last 55 minutes the $\mathrm{Fe}^{2+} / \Sigma \mathrm{Fe}$ ratio increased linearly. The approximate oxygen transfer rate was 0.00956 moles $\mathrm{O}_{2} / \mathrm{min}$, which would accommodate a resin feed rate of 0.459 grams of resin $/ \mathrm{min} .8$

\section{Pilot-Scale}

The feed used for the pilot-scale testing at the Center was different than what was used at SRTC or in the crucible studies at the center. It contained a simulated radioactive sludge portion, frit 202 (borosilicate glass additive), and simulated radioactive supernate material at

approximately 35 - 40 wt: solids. The approximate composition of the three feed portions is given in Table 6.9 The resin used in the testing was loaded with elemental $C s$ at a mass ratio of $0.16 \mathrm{~g}$ of $\mathrm{Cs} / \mathrm{gram}$ of clean dry resin. The resin was approximately $38.4 \%$ solids.

Table 6 - Center Pilot-Scale Feed Component Compositions (Wt 8 )

$\begin{array}{lc}\text { Oxide } & \text { sludge } \\ \mathrm{Al}_{2} \mathrm{O}_{3} & 16.86 \\ \mathrm{~B}_{2} \mathrm{O}_{3} & \text { N/A } \\ \mathrm{BaO} & 0.24 \\ \mathrm{CaO} & 4.39 \\ \mathrm{Cr}_{2} \mathrm{O}_{3} & 0.36 \\ \mathrm{Cs}_{2} \mathrm{O} & 0.01 \\ \mathrm{CuO} & 0.18 \\ \mathrm{Fe}_{2} \mathrm{O}_{3} & 44.12 \\ \mathrm{~K}_{2} \mathrm{O} & 0.39 \\ \mathrm{Li}_{2} \mathrm{O} & \mathrm{N} / \mathrm{A} \\ \mathrm{MgO} & 0.35 \\ \mathrm{MnO}_{2} & 8.91 \\ \mathrm{Na}_{2} \mathrm{O} & 12.77 \\ \mathrm{NiO} & 2.65 \\ \mathrm{PbO} & 0.41 \\ \mathrm{SiO}_{2} & 4.18 \\ \mathrm{TiO}_{2} & \mathrm{~N} / \mathrm{A} \\ \mathrm{ZrO}_{2} & 1.41\end{array}$

\begin{tabular}{c} 
Supernate \\
\hline 1.20 \\
29.30 \\
0.81 \\
0.08 \\
0.02 \\
1.00 \\
3.80 \\
0.81 \\
36.92 \\
$\mathrm{~N} / \mathrm{A}$ \\
0.01 \\
0.16 \\
18.46 \\
0.05 \\
0.01 \\
0.07 \\
7.22 \\
0.02
\end{tabular}

Exit 202
N/A
8.00
N/A
N/A
N/A
N/A
N/A
N/A
N/A
7.00
2.00
N/A
6.00
N/A
N/A
77.00
N/A
N/A


As mentioned earlier, the stirred melter was used for the pilot-scale testing because of the unique advantages it offers to vitrification. By using the stirred melter, crust formation on the melt surface could be reduced because the entire melt is agitated by the impeller and the surface is continuously drawn into the melt. The stirring action also helps ameliorate the negative effects of a reduced melt by constantly refreshing the surface layer, which increases oxygen exchange between the melt and the melter head space vapors. Guidance from the results of the crucible-scale studies, as well as the parameter optimization studies were used to perform the pilot-scale studies at the Center.

For the pilot-scale tests, the ion exchange resin and the combined three stream feed were mixed in a bucket and fed directly to the melter for 20 hours at a rate of $51 \mathrm{~mL} / \mathrm{min}$ using a peristaltic pump. The resin and slurry were mixed at a ratio of 295 grams of the wet loaded resin to 11.312 L of slurry.8 Two samples of this feed were taken for chemical composition analyses. The feed was not started until the melter reached the set-point temperatures, which were $1070^{\circ} \mathrm{C}$ for the melter and $1045^{\circ} \mathrm{C}$ for the auxiliary temperature controllers. A gas sparging system was inserted into the molten bath for the duration of the tests. The oxygen gas was expelled directly under the impeller at a rate of $1200 \mathrm{~mL} / \mathrm{min}$ at STP. 8 The redox probe described above was also used during the test to continuously monitor the glass redox, with readings recorded every few minutes. Glass samples were taken from the exit stream approximately every thirty minutes and at the end of the run.

The analytical results for the chemical composition of the feed to the melter 8 are contained in Table 7. The loss on ignition for the samples was $63.00 \%$ for the initial feed and $66.50 \%$ for the final feed. 8 Results indicated that the composition of the feed to the melter changed over the length of the run. Neither of the results reflects the predicted $\mathrm{Cs}_{2} \mathrm{O}$ content of 0.396 wt\%. This error was partially attributed to analytical error in dissolving and analyzing the samples and also to incomplete mixing in the bucket.

\begin{tabular}{lrr}
\multicolumn{1}{c}{ Table $7-$ Resin Feed Analyses } & (Wt8) \\
Oxide & Initial & Einal \\
\hline $\mathrm{Al}_{2} \mathrm{O}_{3}$ & 2.95 & 3.35 \\
$\mathrm{~B}_{2} \mathrm{O}_{3}$ & 7.77 & 7.60 \\
$\mathrm{CaO}$ & 1.02 & 1.26 \\
$\mathrm{Cr}_{2} \mathrm{O}_{3}$ & 0.13 & 0.16 \\
$\mathrm{Cs}_{2} \mathrm{O}$ & 0.26 & 0.55 \\
$\mathrm{Fe}_{2} \mathrm{O}_{3}$ & 12.05 & 14.20 \\
$\mathrm{~K}_{2} \mathrm{O}$ & 2.39 & 2.90 \\
$\mathrm{Li}_{2} \mathrm{O}$ & 4.85 & 4.50 \\
$\mathrm{MgO}$ & 1.55 & 1.48 \\
$\mathrm{MnO}_{2}$ & 2.63 & 3.12 \\
$\mathrm{Na}_{2} \mathrm{O}$ & 6.46 & 6.54 \\
$\mathrm{NiO}$ & 1.11 & 1.30 \\
$\mathrm{SiO}_{2}$ & 54.35 & 50.75 \\
Total & 97.51 & 97.68
\end{tabular}


Redox measurements taken with the redox probe did not correlate well with the analytical results. These results were not used. However, none of the samples analyzed exceeded 0.33 for the $\mathrm{Fe}^{2+/ \Sigma \mathrm{Fe}}$ ratio and the average after approximately one hour was $0.176 .{ }^{8}$

Four of the glass samples taken during melter operation were analyzed to assist in determining the $C s$ retention for the glass. The results are shown in Table 8 and are identified by their time of sampling into the run.8 The glass analyses results were fairly consistent over the length of the run. The $\mathrm{Cs}_{2} \mathrm{O}$ concentration changed the most, and it increased as more feed was fed to the melter. This behavior was predicted since the glass used to start the melter did not contain any resin.

\section{Table 8 - Center Resin Glass Compositions (Wt 8 )}

\begin{tabular}{|c|c|c|c|c|}
\hline oxide & 0 min. & $627 \mathrm{~min}$ & $920 \mathrm{~min}$. & $1385 \mathrm{~min}$ \\
\hline $\mathrm{Al}_{2} \mathrm{O}_{3}$ & 3.09 & 3.05 & 3.04 & 3.07 \\
\hline $\mathrm{B}_{2} \mathrm{O}_{3}$ & 7.90 & 7.75 & 7.76 & 7.80 \\
\hline $\mathrm{CaO}$ & 1.70 & 1.24 & 1.23 & 1.24 \\
\hline $\mathrm{Cr}_{2} \mathrm{O}_{3}$ & 0.19 & 0.17 & 0.17 & 0.17 \\
\hline $\mathrm{Cs}_{2} \mathrm{O}$ & 0.00 & 0.24 & 0.30 & 0.35 \\
\hline $\mathrm{Fe}_{2} \mathrm{O}_{3}$ & 12.00 & 12.25 & 12.50 & 12.57 \\
\hline $\mathrm{K}_{2} \mathrm{O}$ & 2.43 & 2.70 & 2.76 & 2.76 \\
\hline $\mathrm{Li}_{2} \mathrm{O}$ & 4.75 & 4.79 & 4.82 & 4.80 \\
\hline $\mathrm{MgO}$ & 1.56 & 1.53 & 1.56 & 1.56 \\
\hline $\mathrm{MnO}_{2}$ & 2.64 & 2.74 & 2.80 & 2.80 \\
\hline $\mathrm{Na}_{2} \mathrm{O}$ & 6.69 & 6.69 & 6.73 & 6.76 \\
\hline $\mathrm{NiO}$ & 1.15 & 1.18 & 1.20 & 1.21 \\
\hline $\mathrm{SiO}_{2}$ & 54.10 & 52.70 & 53.55 & 53.67 \\
\hline Total & 98.19 & 97.01 & 98.38 & 98.73 \\
\hline
\end{tabular}

A complete offgas system is connected to the stirred melter. As gasses rose through the riser pipe, they were passed through a combination venturi scrubber/spray quencher, bubbled into a bubbler tank, and then traveled through a counter-current scrubber packed with 0.5 inch Raschig rings. ${ }^{8}$ The scrubber solution was continuously pumped from a reservoir through the column and back into the reservoir. During the melter demonstration, samples from the scrubber and the bubbler were taken approximately every hour. After steady state conditions were reached in the melter (three melter volume turn-overs), the EPA Modified Method 5 Sampling Train and the EPA Multiple Metals Sampling Train were used to take samples of the offgas. Final samples of the scrubber and bubbler solution were also taken for analyses.

Using the results from the feed stream, glass, and offgas analyses, a mass balance for $\mathrm{Cs}$ was performed around the whole system. Due to the inconsistencies in the feed analyses, a range of values for the amount of Cs actually fed to the melter had to be used. The total Cs fed to the melter was 88.18 grams, with a total glass retention of 82.17 grams $(82.3-93.2 \%)$. The total amount of $\mathrm{Cs}$ exiting in the offgas deposits was 0.14 grams, which was about $0.14-0.16 \%$ of the total Cs fed to the 
melter. The total amount of $\mathrm{Cs}$ captured in the bubbler solution was 2.07 grams or $2.1-2.4 \%$ of the total Cs fed to the melter. The total Cs captured in the scrubber solution was 0.215 grams or $0.22-0.24 \%$ of the total Cs fed to the melter. ${ }^{8}$ A summary of the mass balance numbers can be found in Table 9.

Table 9 - Cesium Mass Balance

\author{
Lecation \\ Feed Stream \\ Exit Glass \\ Offgas Deposits \\ Bubbler Solution (Volatile) \\ Scrubber Solution \\ Unaccounted Cs
}

\begin{tabular}{c} 
Grams of Cs \\
\hline $88.18-99.83$ \\
82.17 \\
0.14 \\
2.07 \\
0.22 \\
$15.23-3.58$
\end{tabular}

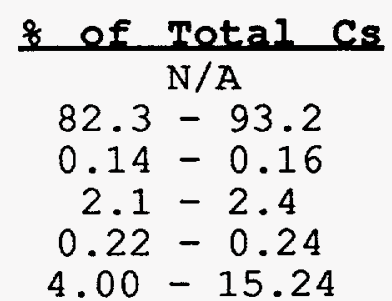

Multiple metals sampling train analysis revealed that less than half of the Cs present in the offgas exists in the volatile form. Several other metals partitioned significantly in the volatile form including $15.2 \%$ lead, $25.4 \% \mathrm{Cr}, 14.5 \% \mathrm{Na}, 10.7 \% \mathrm{Ca}, 15.0 \% \mathrm{Li}$, and $18.5 \% \mathrm{~K}$. The semivolatile organic compounds found in the offgas included benzoic acid, naphthalene, phenanthrene, fluorene, fluoranthrene, and pyrene. 8 This is feasible since the resin is polymer based on resorcinol which is aromatic and all of these were aromatic based.

At a feed rate of 0.50 grams of dry resin per minute, it appeared that there would be no significant problems associated with an over reduced melt.

\section{CONCLUSIONS}

A brief summary of the findings of the SRTC studies summarized in this paper follows:

- For the crucible studies performed at the SRTC, a maximum resin loading of 5 grams of resin/100 grams of glass produced was found.

- In the pilot-scale studies performed at SRTC, resin loadings obtained in the crucible studies were obtained without any significant impact on glass quality or melter operating conditions.

A brief summary of the findings and recommendations of the Center studies summarized above follows:

- For the crucible studies, the average Cs retention was $88.6 \%$ with a standard deviation of $6.6 \%$. No apparent correlation existed between the redox state of the glass and the Cs retention.

- Based on a limited amount of data, the addition of water seemed to result in a more reduced final glass sample. 
September $30,1995 \quad 14$ WSRC-TR-95-0403, Rev.0

- It was determined that slurry feed rate and melter temperature were the two most important operational parameters in achieving successful melter operations. optimum parameters were defined for the stirred melter.

- The oxygen transfer rates under batch type conditions using impeller agitation was 0.0023 moles $\mathrm{O}_{2} / \mathrm{min}$, with water it dropped to 0.00153 moles $\mathrm{O}_{2} / \mathrm{min}$. Under slurry feeding conditions with oxygen sparging, a feed rate of 0.00956 moles $\mathrm{O}_{2} / \mathrm{min}$ was obtained, which is the equivalent of 0.45 grams of dry resin/min.

- Between 82.3 and $93.2 \%$ of the $\mathrm{Cs}$ fed to the melter during the pilot-scale testing was retained in the glass.

- The particulate loading during the pilot scale experiment was approximately $433 \mathrm{mg}$ per cubic meter of offgas at an average temperature of $664^{\circ} \mathrm{C}$. The primary elements found were $\mathrm{C}, \mathrm{B}$, $\mathrm{Fe}, \mathrm{Na}, \mathrm{Mn}, \mathrm{K}, \mathrm{Ca}$, and $\mathrm{Al}$.

- Dilution air pulled thought the offgas treatment system should be minimized in order to allow for accurate calculations of offgas components.

- The rate of oxygen transfer into the glass melt should be maximized so that the corresponding feed rate of resin can also be maximized.

- Offgas sampling should be done at other locations along the offgas treatment system such as downstream from the scrubber and between the bubbler solution tank and the scrubber in order to calculate other values such as scrubber efficiencies.

\section{ACKNOWLEDGEMENTS}

Funding for the summation part of this research and development work was provided by the Department of Energy - Office of Technology Development under the auspices of the Mixed Waste Focus Area and Technical Task Plan SR1-3-20-04. This Technical Task Plan also provided the funding for the studies at the Center. Funding for the studies at the SRTC was provided by the Department of Energy under contract DE-AC09-89SR18035.

\section{REEERENCES}

1. J.P. Bibler and R.M. Wallace, "Testing a New Cesium-Specific Ion Exchange Resin for Decontamination of Alkaline High-Activity Waste", Proceedings of Waste Management 190, edited by R.G. Post, Tucson, AZ (1990), pp. 747-751.

2. R.M. Wallace and J.P. Bibler, "An Improved Method for Decontaminating Soluble High-Level waste Using Ion Exchange", DPST-88-789, E.I. du Pont Nemour \& Co., Aiken, SC (1988). 
3. W.D. Pearson, "Savannah River Site High Level Waste Program and the Defense Waste Processing Facility", Proceedings of the Eifth International symposium on Ceramics in Nuclear and Hazardous waste Management, Cincinnati, OH (1991), pp. 3-10.

4. N.E. Bibler, J.P. Bibler, M.K. Andrews, and C.M. Jantzen, "Initial Demonstration of the Vitrification of Nuclear waste sludge Containing an Organic Cs-Loaded Ion Exchange Resin", WSRC-MS-91465, Westinghouse Savannah River Company, Aiken, SC (1991).

5. W.G. Ramsey, C.M. Jantzen, and D.F. Bickford, "Redox Analyses of SRS Melter Feed Slurry; Interactions Between Nitrate, Formate, and Phenol Based Dopants", Proceedings of the Fifth International Symposium on Ceramics in Nuclear and Hazardous Waste Management, Cincinnati, $\mathrm{OH}$ (1991) pp. 259-266.

6. N.E. Bibler and C.M. Jantzen, "The Product Consistency Test and Its Role in the Waste Acceptance Process", Proceedings of Waste Management 189, edited by R.G. Post, Tucson, AZ (1989) pp. 743-749.

7. C.M. Jantzen, N.E. Bibler, D.C. Beam, C.L. Crawford, and M.A. Picket,, "Characterization of the Defense Waste Processing Facility (DWPF) Environmental Assessment (EA) Glass standard Reference Material", WSRC-TR-92-346, Westinghouse Savannah River Company, Aiken, SC (June 1, 1993).

8. T.N. Sargent, Jr., "Vitrification of Cesium-Contaminated Organic Ion Exchange Resin", Graduate thesis presented to Clemson University - Environmental Systems Engineering (August 5, 1994).

9. R.F. Schumacher, "DWPF Batch 1, Waste Glass Investigations", Proceedings of the Fifth International Symposium on Ceramics in Nuclear and Hazardous Waste Management, Cincinnati, OH (1991) pp. 453-463. 
ATTACHMENT I - SRTC RESORCINOL RESIN PAPER

$\because \stackrel{4}{\square}$ 


\title{
INITIAL DEMONSTRATION OF THE VTTRIFICATION \\ OF HIGH-LEVEL NUCLEAR WASTE SLUDGE CONTAINING AN ORGANIC Cs-LOADED ION EXCHANGE RESIN
}

\author{
N. E. BIBLER, J. P. BIBLER, M. K. ANDREWS, and C. M. JANTZEN Westinghouse
} Savannah River Co., Aiken, SC, 29802

\section{ABSTRACT}

When immobilizing into borosilicate glass the radionuclides in the caustic high-level radioactive wastes stored in the USA, the soluble fission product Cs-137 has to be removed from supernates of the wastes. In the current processes zeolites or an organic precipitant will be used to remove the Cs. These are then treated further and mixed with the radioactive sludges and vitrified into a borosilicate glass. This paper describes the vitrification of a mixture resulting from using a new process to remove $C$ s from the caustic supernate. A resorcinol based organic ion exchange resin is used. This resin was then mixed with sludge and frit and vitrified. Using an organic ion exchange resin rather than zeolite or the organic precipitant has certain advantages. For example, use of the zeolite increases the amount of glass to be made and use of the organic precipitant produces benzene as a secondary waste stream. Results in the paper indicate that a mixture of the resin, sludge and frit can be successfully vitrified in a joule-heated, slurry fed melter. However, when resin is present in the feed, the glass becomes less durable due to the increased amount of Fe(II) caused by reduction of Fe(III) in the melt. Based on the durabilities of other waste glasses, this glass is still suitable as a canistered wasteform.

\section{INTRODUCTION}

At the Hanford, West Valley, and the Savannah River Site (SRS), high-level radioactive nuclear wastes will be immobilized into borosilicate glass for permanent disposal in a geologic repository. At all three sites, the wastes are stored as caustic slurries in million gallon underground tanks. Since the slurries are caustic, most of the fission products and the transuranic waste radionuclides are precipitated in a sludge as hydrous oxides; however, since $\mathrm{C} s$ is soluble in caustic slurries, most of the radioactive Cs-137 is in the supernate along with high concentrations of $\mathrm{Na}^{+}$ions $(-4 \mathrm{M})$ added as $\mathrm{NaOH}$. Consequently, Cs-137 has to be removed from the supernate and consolidated with the sludge in order to immobilize all the radioactivity into the glass. At Hanford and West Valley, an inorganic zeolite mineral is used in the reference process to remove Cs. This zeolite will be mixed with sludge and an appropriate frit and then fed into a melter at $1150^{\circ} \mathrm{C}$. The supernates at Savannah River Site (SRS) are too caustic to allow the use of zeolite. Cesium will be precipitated as cesium tetraphenylborate (CsTPB). Potassium is also precipitated from the supernate as KTPB. The tetraphenylborate precipitates will then be decomposed by hydrolysis. This produces benzene which is removed in order to reduce the amount of carbon going into the melter. The product of this hydrolysis will be mixed with the sludge and frit and then fed to a melter.

Recently, an organic ion exchange resin has been developed that can successfully compete with high concentrations of $\mathrm{Na}^{+}$ions in the caustic supernates and remove the $\mathrm{Cs} .1$ This resin has been tested on both actual and simulated radioactive supernates. Is a second generation process at SRS, we are investigating the possibility of using this resin to remove Cs and then mixing the Cs-loaded resin with sludge and frit and feeding the mixture directly into a melter to make glass. The resin will be incinerated in the melter and the residual $\mathrm{Cs}$ immobilized in the borosilicate glass. This process has advantages over both the zeolite and the CSTPB precipitation processes. Because the resin is burned and zeolites are not, this process would produce less glass than the zeolite process. There are two apparent advantages over the CSTPB process. First, the resin process does not produce a secondary waste stream as does the CSTPB process. In the CsTPB process, benzene is produced by the hydrolysis process anr? 
has to be stored or destroyed. Second, with the resin process, the need for the complicated hydrolysis process is eliminated altogether. However, as with any new process, integration of the ion exchange streams with other streams in the process and the burning of the spent resin in the melter has to be demonstrated on a pilot scale before the actual performance of the overall process can be accurately assessed.

This paper describes three kilogram scale melter runs designed to test whether a durable glass could be made by feeding a slurry of sludge, frit, and the organic resin to a joule-heated melter. Because the organics in the feed might reduce redox elements such as $\mathrm{Fe}$, the redox of the final glass was measured by determining the $\mathrm{Fe}$ (II) content of the glass. The durability of the glass was measured by the Product Consistency Test (PCT). Another goal was to determine if the presence of resin significantly altered the performance of the melter and offgas system. Each meiter run used nominally $120 \mathrm{~kg}$ of slurry, lasted three days and produced nominally $30 \mathrm{~kg}$ of glass. Prior to using the large melter, small scale crucible tests were performed to determine how the resin will affect the redox of the melt.

\section{EXPERIMENTAL}

The melter was a ceramic-lined, joule-heated melter that held nominally $18 \mathrm{~kg}$ of glass in its melt chamber. Feed for the melter was a slurry (nominally 58 weight percent water) containing the sludge, frit and resin. The melt was at $1150^{\circ} \mathrm{C}$. During the feeding process as the slurry fell on the top surface of the melt, water was flashed off, any organic present was incinerated, sludge was dissolved in the melt, and the frit was melted. Molten glass was poured from the bottom of the melt into one liter stainless steel beakers. The off-gas system collected the condensate from the water fed to the melter, as well as particulates entrained in the off-gas.

Three melter runs were performed. Each run contained the same simulated sludge and frit. Resin was added to the feed for the second and third run. For the first two runs the melter was fed for three 16-hour intervals and one 8-hour interval over three days. The melter idled for 8 hours each of the first two days. The first run contained only frit and sludge and was performed to determine the quality of the glass when resin was not in the feed. The second run was identical to the first except that resin had been added to the feed. In the third run, the melter was fed continuously for 53 hours or 2.2 days. Each run produced 12 cans of glass with each can holding approximately $2 \mathrm{~kg}$.

The durability of the glass was determined by subjecting samples of the glass from various cans to the PCT. ${ }^{2}$ This is a crushed glass leach test at $90^{\circ} \mathrm{C}$ using deionized water. The crushed glass (100-200 mesh) is leached for 7 days and the amount of soluble elements (B, $\mathrm{Na}, \mathrm{Li}$, and $\mathrm{Si}$ ) released to the solution measured to determine the durability of the glass. The final $\mathrm{pH}$ of the leachate was also measured and is an indication of the durability of the glass. Crushed glass was obtained by grinding pieces of glass that were taken from the liter stainless steel cans using a hammer and chisel. The grinder contained a tungsten carbide blade to prevent iron contamination of the glass.

The redox property of the glass was measured by determining the $\mathrm{Fe}$ (II) content of the glass. A colorimetric technique was used after $\mathrm{HF} / \mathrm{HCl}$ dissolution of crushed samples of glass. ${ }^{4}$

\section{RESULTS AND DISCUSSION}

\section{Preliminary Crucible Tests}

To determine how the resin would affect the redox of the glass melt, small crucible tests were performed using varying amounts of resin and an oxidizing agent, nitrate ions. In 
these tests, the mixure of resin, sludge, and frit was dried and then melted for four hours at $1150^{\circ} \mathrm{C}$. The glass was quenched and the $\mathrm{Fe}(\mathrm{II})$ content of the glass measured. The results of these tests indicated that with increasing amounts of resin in the feed, more $\mathrm{Fe}$ (II) was present in the glass. The results also showed that both $\mathrm{NaNO}_{3}$ and $\mathrm{HNO}_{3}$ were effective in lowering the amount of $\mathrm{Fe}$ (II) formed. $\mathrm{HNO}_{3}$ was more effective than $\mathrm{NaNO}_{3}$. The crucible tests indicated that at a ratio of 5 grams of resin per 100 grams of glass, the $\mathrm{Fe}(\mathrm{II}) / \mathrm{Fe}$ (total) ratio should be $\sim 0.3$. This value has been proposed as an upper limit on the amount $\mathrm{Fe}$ (II) that should be present in the nuclear waste glasses that will be produced at SRS. ${ }^{4}$ This upper limit is based on the standard state calculation of the stability of nickel sulfide in the melt. ${ }^{5}$ If nickel sulfide forms, it is conductive and may create an electrical short and damage the melter electrodes. For the resin runs, it was decided to use enough resin to approach this upper limit, thus, 5 grams of resin were used for every 100 grams of glass expected in the run.

\section{Melter Feed Composition}

Table I shows the major composition (on the basis of total solids in the slurry after it is dried) of the simulated nuclear waste sludge used in this study. This composition is typical for the sludges that will be processed at SRS. When the sludge is present as melter feed, it

\section{TABLE I. MAJOR COMPONENTS IN A DRIED SRS SIMULATED SLUDGE}

\begin{tabular}{lc} 
Element & $\begin{array}{c}\text { Weight } \\
\text { Percent }\end{array}$ \\
\hline $\mathrm{Fe}$ & 12.1 \\
$\mathrm{Si}$ & 5.1 \\
$\mathrm{Mn}$ & 2.8 \\
$\mathrm{~B}$ & 0.64 \\
$\mathrm{Mg}$ & 0.30
\end{tabular}

\begin{tabular}{cc} 
Element & $\begin{array}{c}\text { Weight } \\
\text { Percent }\end{array}$ \\
\hline $\mathrm{Na}$ & 7.1 \\
$\mathrm{Al}$ & 3.5 \\
$\mathrm{Ca}$ & 1.7 \\
$\mathrm{Li}$ & 0.53 \\
$\mathrm{Zn}$ & 0.20
\end{tabular}

will be in a slurry that contains soluble formates, nitrates, and nitrites. Formate is alded to adjust the rheology of the sludge and reduce $\mathrm{Hg}$ which is distilled from the sludge prior to feeding it into the melter. Nitrates and nitrites are present in the original sludge while it is stored in the waste tanks. Nominal concentrations of these anions are $1.2 \mathrm{M}$ for formate, $0.4 \mathrm{M}$ for nitrate, and $0.1 \mathrm{M}$ for nitrite. The frit used was Frit 165 . Its composition is given in Table II. The final glass is 28 weight percent sludge oxides and 72 weight percent frit oxides.

\section{TABLE II: OXIDE COMPOSITION OF FRIT 165}

$\begin{array}{lccc} & \text { Weight } & & \text { Weight } \\ \text { Oxide } & \begin{array}{l}\text { Oxide } \\ \mathrm{SiO}_{2}\end{array} & \frac{\text { Percent }}{\mathrm{Na}_{2} \mathrm{O}} & \frac{1}{\text { Percent }} \\ \mathrm{B}_{2} \mathrm{O}_{3} & 65.0 & \mathrm{Li}_{2} \mathrm{O} & 6.9 \\ \mathrm{ZrO}_{2} & 10.5 & \mathrm{TiO}_{2} & 2.0 \\ \mathrm{~K}_{2} \mathrm{O} & 2.4 & \mathrm{MgO} & 0.64 \\ \mathrm{PbO}_{2} & 1.0 & \mathrm{CaO} & 0.23 \\ \mathrm{Al}_{2} \mathrm{O}_{3} & 0.2 & \mathrm{Fe}_{2} \mathrm{O}_{3} & 0.04\end{array}$

The elemental composition of the Cs-loaded resin is given in Table III. Prior to putting the resin into the melter feedtank, the resin was saturated with Cs by removing Cs from a simulated radioactive caustic supernate. The composition of this supernate was 4.0 $\mathrm{M} \mathrm{NaNO}_{3}, 1.5 \mathrm{M} \mathrm{NaOH}$, and $2.5 \times 10^{-4} \mathrm{M} \mathrm{CsNO}_{3}$. The $\mathrm{Na}$ form of the resin was used. To have enough resin for both runs, approximately $3 \mathrm{~kg}$ of dry resin were needed. This amo:?: of resin was used to remove the Cs from 1700 liters of simulated supernate. The only pretreatment of the resin prior to adding it to the melter feedtank was to filter it from the supernate and air dry. (Air drying would probably not be necessary during large scale 


\section{TABLE II: ELEMENTAL COMPOSITION OF DRIED CS SPECIFIC ION EXCHANGE RESIN AFTER REMOVING CS FROM A SIMULATED HLW SUPERNATE}

\begin{tabular}{cccc} 
& Weight & Weight \\
Element & Percent & Element & Percent \\
\hline $\mathrm{C}$ & 35.5 & $\mathrm{O}$ & 45.5 \\
$\mathrm{Na}$ & 7.0 & $\mathrm{H}$ & 5.8 \\
$\mathrm{Cs}$ & 0.95 & $\mathrm{~K}$ & 0.07
\end{tabular}

processing.) The correct amount of dried resin was then mixed with the sludge and frit siurry in the melter feedtank.

Addition of the resin adds negligible amounts of alkali metals to the glass. For example, based on the composition in Table III, the presence of the resin adds only -0.4 weight percent $\mathrm{Na}$ and 0.004 weight percent $\mathrm{K}$ to the glass. The amount of $\mathrm{Cs}$ added is even lower.

\section{Effect of Resin on Melter Operation}

When resin was present in the feed, no differences in melter operation were evident. There was no effect of resin on the required amount of current to pass through the electrodes in order to maintain the melt at $1150^{\circ} \mathrm{C}$. This suggests that the resin did not produce any conductive species in the melt which would short out the electrodes. The presence of the resin also did not introduce any adverse effects such as pluggage of the meiter feed tube or off-gas systern. Finally there was no apparent affect on the pourability (viscosity) of the glass melt.

\section{Einal Glass Compositions}

The composition of a sample of glass from each of the three runs is given in Tatle IV. For the sludge only run (Run 1) and the intermittent sludge-resin run (Run 2), the samples were taken from the seventh can collected. For the continuous resin run, the sample was taken from the third can collected. Except for the Fe(II) and Fe(III) contents, the compositions are $z$ similar. This is expected because the only difference in the feed was whether resin was present or not. When resin was present, the amount of Fe(II) increased which indicates that the glass is in a more reduced state. Further, in the melter run where the melter had been fed continuously for $\mathbf{2 . 2}$ days, the amount of Fe(II) increased the most (see Table IV).

\section{Effect of Resin on Glass Redox and Durability}

Table $V$ summarizes the results for the redox ratios (Fe(II)/Fe(total)) and the durabilities for samples of glass from five of the twelve cans collected in each of the three melter runs. The cans were collected in the numerical sequence given by the sample numbers in the first column of Table V. For example, Sample 2-07 was from the 7th can collected in the second run (the intermittent resin run). As each run progressed (run times given in column 2), the glass became more reduced (the iron redox ratio increased) and less durable as measured by the PCT. Lower durabilities are indicated by the increased $\mathrm{pH}$ values (Column 4) and $\mathrm{B}$ concentrations (Column 5) in the PCT tests. Similar trends were indicated by the $\mathrm{Na}, \mathrm{Li}$, and $\mathrm{Si}$ leached from the glass in the PCT tests. The pH increases are due to hydronium ions in the leach water exchanging with alkali ions in the glass. An increase in the Fe(H) in the glass decreases its durability because $\mathrm{Fe}$ (II) acts as a network modifier in the glass, while Fe(III) can be a network former. In the sludge only run, reduction in the melt was caused by formic acid. When resin was present, increased reduction was caused by the organic resin. 
TABLE IV: COMPOSITIONS OF THREE GLASSES FROM THREE MELTER RUNS TESTING THE EFFECT OF ORGANIC RESIN ON SLUDGE VITRIFICATION

\begin{tabular}{c}
\hline Glass-1-07 \\
\hline 1.21 \\
4.04 \\
7.32 \\
.92 \\
.37 \\
8.53 \\
1.05 \\
4.51 \\
0.77 \\
1.48 \\
11.69 \\
0.69 \\
50.2 \\
1.06 \\
0.17 \\
1.26
\end{tabular}

Composition (weight percent)

Oxide
$\mathrm{K}_{2} \mathrm{O}$
$\mathrm{Al}_{2} \mathrm{O}_{3}$
$\mathrm{~B}_{2} \mathrm{O}_{3}$
$\mathrm{CaO}$
$\mathrm{Cr}_{2} \mathrm{O}_{3}$
$\mathrm{Fe}_{2} \mathrm{O}_{3}$
$\mathrm{FeO}$
$\mathrm{Li} 2 \mathrm{O}$
$\mathrm{MgO}$
$\mathrm{MnO}$
$\mathrm{Na} \mathrm{O}$
$\mathrm{NiO}$
$\mathrm{SiO}_{2}$
$\mathrm{TiO}_{2}$
$\mathrm{ZnO}$
$\mathrm{ZnO}_{2}$

1.26
Glass-2-0 $\frac{07^{b}}{0.96}$

0.96

3.62

7.16

.81

.38

2.82

4.65

0.74

1.43

12.13

0.58

50.1

1.06

0.18

1.36
Glass-3-03c

1.0

3.77

6.62

.87

.33

6.64

3.15

4.45

0.73

1.56

$\because 11.91$

0.55

49.6

1.01

0.22

1.31

aGlass from $\operatorname{Can} 7$ of the intermittent sludge only run.

bGlass from Can 7 of the intermittent sludge-resin run.

cGlass from Can 3 of the continuous sludge-resin run.

TABLE V: IRON REDOX RATIO AND PCT RESPONSE FOR GLÁSS SAMPLES FROM VITRIFICATION OF A SLURRY OF FRIT, SIMULATED HLW SLUDGE AND AN ORGANIC ION EXCHANGE RESIN

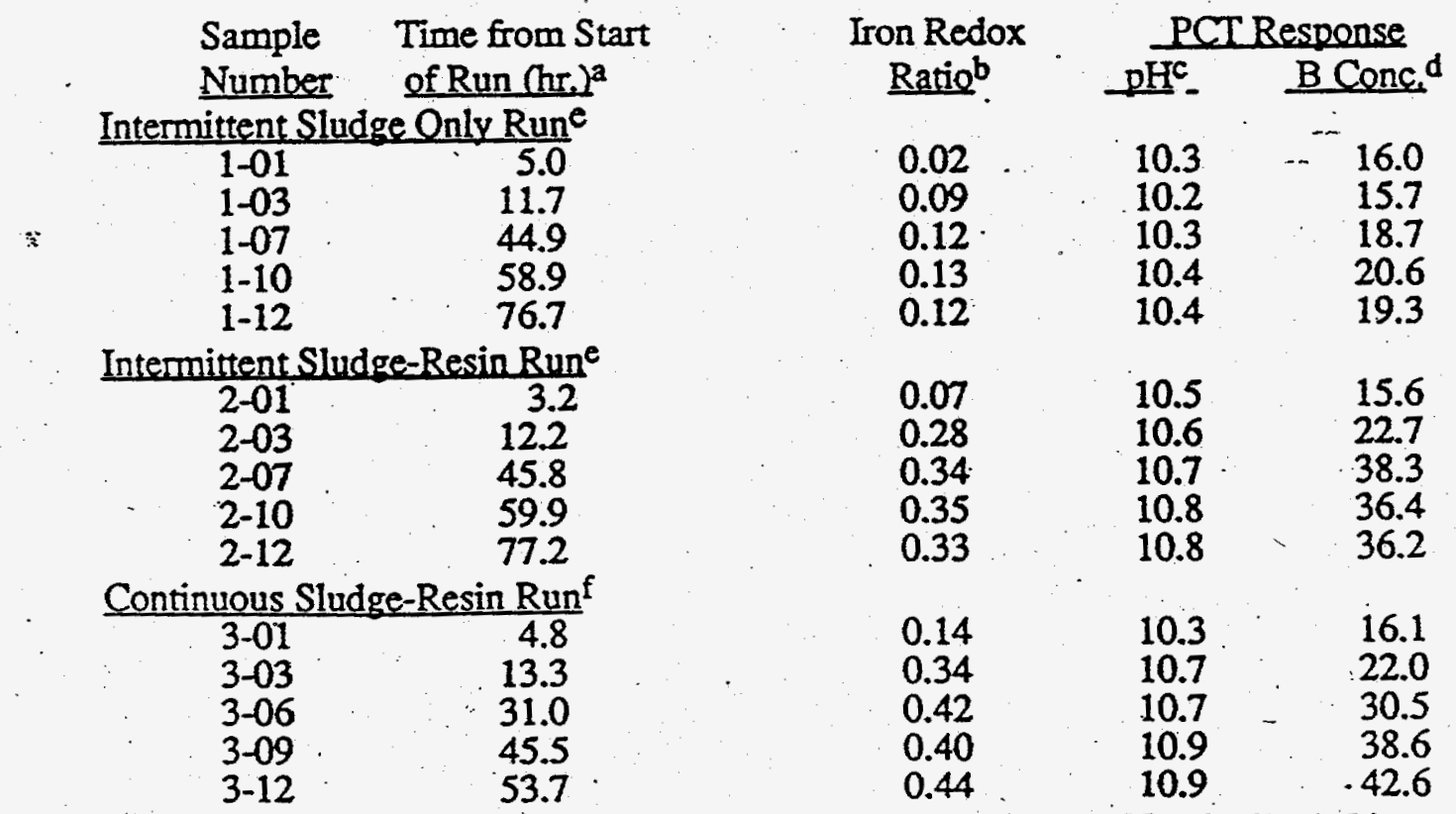

aTime that the can was removed from the melter pour chamber. Nominally 45 hours were required to fill a can.

bMeasured $\mathrm{Fe}(\mathrm{II}) / \mathrm{Fe}$ (total) ratio in the glass.

${ }^{c}$ Final $\mathrm{pH}$ in the PCT leach test. Initial $\mathrm{pH}=6.5$.

dFinal boron concentration (ppm) in the PCT leach test. Initial $=0.0$.

eMelter was fed and glass poured for three 16 hour and one 8 hour intervals with 8 hour intervals in between. Total time $=3.2$ days.

$\mathrm{f}_{\mathrm{Melter}}$ was fed and glass noure $\mathrm{n}$..... 
The glass collected in the first can from each run is more oxidized and more durable than the glass collected later in the runs. This is because the melter idled at $1050^{\circ} \mathrm{C}$ for several days between runs. During this idling period, $O_{2}$ diffused into the melt and reoxidized the Fe. Thus, the glass collected in the first can in the next run would be from this oxidized melt. The most reduced glass had a redox ratio of 0.44 and resulted from the continuous resin run (Run $3)$. In the two resin nuns, the redox ratio of the glass in many cans exceeded the upper limit of 0.3 proposed ${ }^{4}$ for this ratio. However, during these runs, there was no indication of electrical shorting in the melter. We are now examining the glass by scanning electron microscopy to see if any reduced metals are present. The final redox ratios in the intermittent resin run were not as high as the continuous resin run. During the intermittent run, $\mathrm{O}_{2}$ diffused into the melt during the 8 hours per day when the melter was idling. Consequently, the melt did not become as reduced as in the continuous run.

The acceptability of the glass from this process as a waste form for SRS radioactive waste can be assessed by comparing its durability with that of the glass which has been qualified in the DWPF Environmental Assessment (EA glass). Preliminary PCT results ${ }^{6}$ with the EA glass indicate a $B$ concentration nominally $10 \mathrm{X}$ higher than the highest $B$ concentration in Table $V$. On this basis, it can be concluded that glass prepared by vitrification of waste containing an organic ion exchange resin would be acceptable as a canistered waste material.

\section{CONCLUSIONS}

1. An organic ion excharge resin can be mixed with simulated high-level radioactive waste sludge and frit and then successfully vitrified in a slurry fed, joule-heated melter.

2. The resin does not significantly affect the operation of the melter and off-gas system However, this will have to be further tested with longer runs and a larger melter.

3. The resin causes the glass to become more reduced which decreases its durability. However, when compared to preliminary PCT results with the DWPF EA glass, this glass is acceptable for the immobilization of radioactive waste.

\section{FUTURE WORK}

The advantages of using an organic ion exchange resin for removing Cs from caustic supernates justify further tests to refine the vitrification process. Efforts will be made to adjust the melter feed to produce a more oxidized and durable glass. For example, based on the crucible tests, if nitric rather than formic acid is used to adjust the rheology of the sludge, the glass will be more oxidized. Further, it may be possible to reduce the amount of resin in the feed and still have enough resin to remove Cs-137 from the supernates. Lastly, methods of eluting the Cs off the resin need to be investigated.

\section{ACKNOWLEDGMENT}

- This work was done under Contract No. DE-AC09-89SR18035 with the U.S. Department of Energy. 


\section{REFERENCES}

1. J. P. Bibler and R. M. Wallace, "Testing a New Cesium-Specific Ion Exchange Resin for Decontamination of Alkaline High-Activity Waste," Proceedings of Waste

Management ' 90 , edited by R. G. Post, Tucson, AZ, (1990), pp. 747-751.

2. N. E. Bibler and C. M. Jantzen, "The Product Consistency Test and Its Role in the Waste Acceptance Process," Proceedings of Waste Management '89, edited by R. G. Post, Tucson, AZ, (1989)pp.743-749.

3. C. J. Coleman, E. W. Bauman, and N. E. Bibler "Colorimetric Determination of $\mathrm{Fe}$ (I)/Fe(III) Ratio in Radioactive Glasses," Broceedings of the Intemational High-Level Radioactive Waste Management Conference, (American Nuclear Society, Inc., La Grange Park, IL, 1992), p. 557-561.

4. D. F. Bickford A. A. Ramsey C. M. Jantzen AND K. G. Brown, "Control of Radioactive Waste Glass Melters: I. Preliminary General Limits at Savannah River," L Am. Ceram. Soc. 73, pp. 2896-2902 (1990).

5. D. F. Bickford and R. B. Diemer, Jr., "Redox Control of Electric Melters with Complex Feed Compositions, Part. I," L. NonCryst. Solids. 84, pp. 276-284 (1986).

6. N. D. Hutson, C. M. Jantzen, and D. C. Beam, "A Pilot Scale Demonstration of the DWPF Process Control and Product Verification Strategy," Proceedings of the Intemational

High-Level Radioactive Waste Management Conference, (American Nuclear Society, Inc., La Grange Park, IL, 1992), pp. 524-532. 
ATTACHMENT II - CENTER RESORCINOL RESIN THESIS 
ATTACHMENT III - MONTHLY REPORTS FOR THE DOE/INDUSTRIAL CENTER FOR VITRIFICATION RESEARCH 


\section{College of Engineering}

ENVIRONMENTAL SYSTEMS ENGINEERING

Thomas J. Overcamp, Ph.D., P.E.

(803) 656-5573

Fax (803) 656-0672

tivo@ese.clemsonedu

\section{Memorandum}

To: $\quad$ Edward A. Hamilton, Acting Chief Operating Officer

South Carolina Universities Research and Education Foundation

Strom Thurmond Institute

Clemson, SC 29634-5701

From: Thomas J. Overcamp

Subject: $\quad$ SCUREF Monthly Status Report, August 1995

Task Order No. 121, Phase II Vitrification Program

Date: $\quad$ October 3, 1995

Enclosed is the Monthly Status Report for Task Order No. 121, "Demonstration of Vitrification on Surrogate Wasteforms in Support of DOE Process Based Delisting Petitions." This report covers the period beginning 1 August 1995 and completing 31 August 1995.

Please contact me if you have any questions.

Thank you.

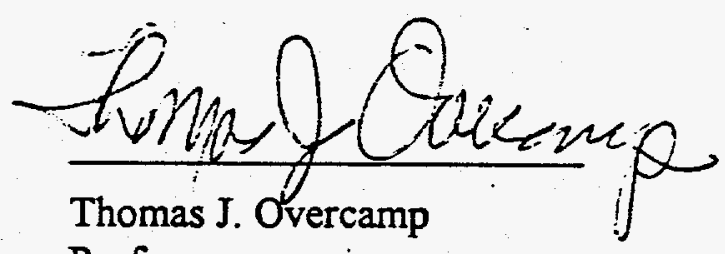

Professor

xc. J. Bailey, WSRC Procurement Administrator

D. Bickford, WSRTC Technical Representative

$\checkmark$ C. Cicero, WSRC Technical Representative

D. Helton, WSRC/DOE

T. Keinath, Clemson COE

D. L. Erich, ESE

S. S. Clipp, ESE

H. D. Rees, ESE 
Edward A Hamilton, SCUREF

Strom Thurmond Institute, Clemson University

Clemson, South Carolina 29634-5701

University: Clemson University $\quad$ P.I. Dr. Thomas J. Overcamp

Project Title: Demonstration of Vitrification on Surrogate Wasteforms in Support of DOE Process Based Delisting Petitions

Period of Performance: From 8/1/95 to $\underline{8 / 31 / 95}$

WSRC Technical

Representative: Dennis Bickford

\section{A. Project Accomplishments:}

The LANL run in the Envitco EV-16 meiter experienced several problems that delayed and or temporarily stopped the run. O-dichlorobenzene was added at a level of $10 \mathrm{~g} /(\mathrm{kg}$ sludge) to the feed as suggested by Bostick's work (MWIP-18). This was an option that could be used for testing destruction efficiency of the melter. Since we are not scheduled to do organic emissions analysis, this was not needed. Since the aqueous solubility of odichlorobenzene is only about $100-150 \mathrm{~g} / \mathrm{m}^{3}$ and since there was no other organic matter in the sludge, the amount added far exceeded the slurry's capacity. Volatilization of dichlorobenzene occurred causing concern over the potential level of vapors in the workspace. The tank was covered and respirators were supplied for critical operations such as tank inspection and operations with the melter door open. Air sampling was performed above the sealed tank. The concentrations were well below the 8 hour TWA for 0 -dichlorobenzene.

The Zermal refractory was delivered with a $2.5^{\prime \prime}$ hole for the electrodes instead of a $2.375^{n}$ hole. Since we did not think that it would be a problem, the block was installed. After startup on the LANL sludge, glass leak from electrode port on August 7. The melter was shut down and the electrodes were grouted in place on August 14. The melter was restarted on August 16. The melter was put on hot hold on August 18. Inspection on August 19, showed that the melter had shut down. This had probably occurred because of the design of the power supply. When the glass cools, its resistivity increases. The power supply increases the voltage. When the voltage reaches the top of the range for the transformer tap, the voltage is not increased. Gradually, the current drops and the melter shut down. The melter was started on August 21. Feeding progressed slowly at $0.035-0.04 \mathrm{gal} / \mathrm{minute}$.

On August 26 during the routine draining of glass, the drain probe failed to close and much of the glass in the melter drained onto the floor of the lab. Apparently, the drain probe was misaligned and either missed the drain or was jammed onto the top edge of the drain. Damage done to water cooling hoses, a nitrogen hose connected to the drain, and electrical cables were damaged by molten glass. Since the glass drained down to the electrode level, the tops of the electrode caps were exposed and apparently oxidized. The tops of the electrodes were flattened. Repairs were made. The drain probe was realigned and the screw jack was replaced with a new one of larger capacity. In addition, the electrical power, water cooling hoses, and the nitrogen lines were put in overhead cable trays to prevent damage due to such incidents. This allowed us to remove the wooden platforms from between the melter and the power and service modules. Addition safety precautions that were taken included (1) the installation of a nonconductive rubber mats between the melter and the power module and on the melter platform to protect operators, (2) a sawed-off 55 gallon drum was placed below the roller conveyor below the melter to capture a glass spill, and (3) a large exhaust fan for the laboratory. The spilled glass was crushed and on August 31 we awaited word from WSRC about restarting the run once more.

We initiated extensive repairs and modifications on the DC Arc Melter due to the failure of the water-cooled electrical cables feeding the graphite electrode. This electrode was also realigned to stop its scraping on the side of the melter's top and to improve the smoothness of its motion. 
Monthly copying and archiving of notebooks was conducted as required.

\section{B. Milestones Achieved:}

The LANL run was initiated.

C. Problems Encountered

Many problems were experienced in the LANL runs as noted above.

Reported by T. J. Overcamp 


\section{College of Engineering}

ENVIRONMENTAL SYSTEMS ENGINEERING

Thomas J. Overcamp, Ph.D., P.E.

(803) 656-5573

Fax (803) 656-0672

ijvro@ese.clemson.edu

\section{Memorandum}

To: $\quad$ Dr. Judith L. Bostock, Chief Operating Officer

South Carolina Universities Research and Education Foundation

Strom Thurmond Institute

Clemson, SC 29634-5701

From: $\quad$ Thomas J. Overcamp

Subject: $\quad$ SCUREF Monthly Status Report, February, 1995

Task Order No. 121, Phase II Vitrification Program

Date: March 18, 1995

Enclosed is the Monthly Status Report for Task Order No. 121, "Demonstration of Vitrification on Surrogate Wasteforms in Support of DOE Process Based Delisting Petitions." This report covers the period beginning 1 February 1995 and completing 28 February 1995.

Please don't hesitate to contact me if you have any questions.

Thank you.

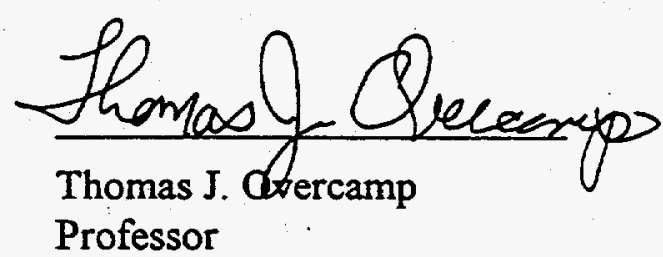

xc. J. Bailey, WSRC Procurement Administrator

D. Bickford, WSRTC Technical Representative

C. Cicero, WSRC Technical Representative

D. Helton, WSRC/DOE

Dr. T. Keinath, Clemson COE

D. M. Bennert, ESE

S. S. Clipp, ESE 
Dr. Judith L. Bostock, SCUREF

Strom Thurmond Institute, Clemson University

Clemson, South Carolina 29634-5701

University: Clemson University

P.I. Dr. Thomas J. Overcamp

Project Title: Demonstration of Vitrification on Surrogate Wasteforms in Support of DOE Process Based Delisting Petitions

Period of Performance: From 2/1/95 to 2/28/95

WSRC Technical

Representative:

Dennis Bickford

\section{A. Project Accomplishments:}

Stir Melter tests for Rocky Flats surrogate have been delayed due to problems with the composition and inability to control the Joule-heated power to the melter. See Problems Encountered. These tests are being rescheduled for March.

Preparations are underway for the graphite are melter that is expected in early March. Space is being made for the unit by moving much of the raw material storage to leased space in the Foundation Seed warehouse. The area currently utilized for storage will be dedicated to the arc meiter. Additional details on the arc melter are needed from WSRC. See Problems Encountered.

Preparation of a proposal to South Carolina Research Authority to make the existing laboratory a permanent facility. Architects have been identified to make conceptual design proposals on expansion and facelift to existing structure. A presentation will be presented to them on April 13, 1995.

Meeting was held on February 8-10, 1995, with representatives of WSRC and ORNL/ORR to discuss the path forward for the demonstration of the TVS at Clemson. Meeting focused on ORR personnel training, test plans, waste composition, information generation. Current schedules indicate delivery of TVS to Clemson in early August.

John Harden attended the Informex chemical manufacturers trade show in Nashville to speak to manufacturers about preparing the TVS feed.

SOS174-EC, "Check-Out of the Transportable Vitrification System," was received and work has started on preparing a proposal.

Testing of the new Envitco WETF tests OR1-2, OR1-3, and OR1-4 are scheduled to begin the week of March 27 at Clemson.

Preparations for the new WETF tests continue. We are (1) working with WSRC on the glass composition for the tests; (2) development of a high-solids slurry for feeding the melter by selecting silica sources with the correct size distribution; and (3) preparations of the melter.

Drafts of the VITSOP "Verification of Calculations" was approved. A new purchasing and inspection form was initiated. 
Judith L. Bostock

March 18, 1995

Page 2

A study of our accounting system has been initiated to determine how we most efficiently keep track of project expenses by task to improve our managerial control of the project.

Another four hour training session was conducted for the staff and students of the Vitrification Laboratory. This emphasized operations of the melters and other laboratory procedures.

Bob Dalton visited WSRC on February 27, 1995 to discuss (1) the glass compositions for the new WETF runs, OR1-2, OR1-3, and OR1-4, (2) to discuss our slurry development work for WETF, and (3) to discuss the testing of the Discflo pump that will occur at Clemson.

Ken Kormanyous of Stir Melter visited the Vitrification Laboratory on February 16, 1995 to learn of our operational problems with the Stir Melter. We also discussed future initiatives for the Stir Melter in our program.

Dr. Resce presented "The Effect of Chemical Composition on the PCT Durability of Mixed Waste Glasses from Wastewater Treatment Sludges," and "The Elemental Analysis of Waste Glass by X-Ray Fluorescence Spectrometry," atWaste Management '95, in Tueson, AZ.

Interviews were held for the position of Managing Director of the Vitrification Laboratory.

Monthly copying and archiving of notebooks was conducted.

B. Milestones Achieved:

Work progress on the Rocky Flats tests, and the final reports for the M-Area and the original WETF tests.

\section{Problems Encountered:}

The coil on the steam generator failed due to the expansion of freezing water A replacement has been ordered.

The power unit control on the Stir Melter continues to be a problem. The inability to control the power has delayed running the RF-2 test.

Reported by T. J. Overcamp 


\section{College of Engineering}

ENVIRONMENTAL SYSTEMS ENGINEERING

(803) 656-5573

Fax (803) 656-0672

tjvro@ese.clemsonedu

\section{Memorandum}

To:

Dr. Judith L. Bostock, Chief Operating Officer

South Carolina Universities Research and Education Foundation

Strom Thurmond Institute

Clemson, SC 29634-5701

From: Thomas J. Overcamp

Subject: $\quad$ SCUREF Monthly Status Report, March, 1995

Task Order No. 121, Phase II Vitrification Program

Date: $\quad$ April 17, 1995

Enclosed is the Monthly Status Report for Task Order No. 121, "Demonstration of Vitrification on Surrogate Wasteforms in Support of DOE Process Based Delisting Petitions." This report covers the period beginning 1 March 1995 and completing 30 March 1995.

Please don't hesitate to contact me if you have any questions.

Thank you.

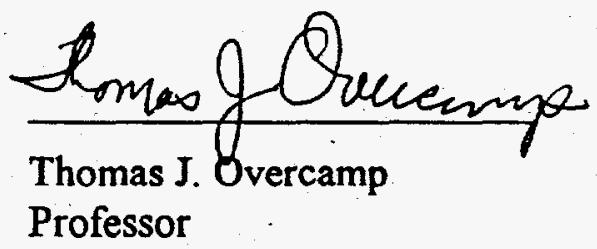

-xc. J. Bailey, WSRC Procurement Administrator

D. Bickford, WSRTC Technical Representative

C. Cicero, WSRC Technical Representative

D. Helton, WSRC/DOE

Dr. T. Keinath, Clemson COE

D. M. Bennert, ESE

S. S. Clipp, ESE 
Dr. Judith L. Bostock, SCUREF

Strom Thurmond Institute, Clemson University

Clemson, South Carolina 29634-5701

University: Clemson Universily

P.L.

Dr. Thomas J. Overcamp

Project Title: Demonstration of Vitrification on Surrogate Wasteforms in Support of DOE Process Based Delisting Petitions

Period of Performance: From 3/1/95 to 3/31/95

WSRC Technical

Representative: Dennis Bickford

\section{A. Project Accomplishments:}

Stir Melter tests for Rocky Flats surrogate was delayed until April due to continuing problems with the power control unit.

Envitco Melter tests for Rocky Flats surrogate have been completed. All samples in the run plan were taken. Three volumes of glass were not produced as discussed below.

Preparations were completed for delivery of the graphite arc melter. Space was made for the unit by moving much of the raw material storage to leased space in the Foundation Seed warehouse. After several delays, the arc melter was delivered on March 17 and put in place that same day. Piping and electrical connections were scheduled for the following two weeks.

A proposal to the South Carolina Research Authority to make the existing laboratory a permanent facility was developed. An architect completed a first set of conceptual designs for expansion and facelift of the existing structure. The proposal and drawings will be presented to the Authority's board on April 13, 1995.

A proposal in response to SOS174-EC, "Check-Out of the Transportable Vitrification System," was developed during March and delivered to SCUREF on the 21 st.

Testing of the new Envitco WETF tests OR1-2, OR 1-3, and OR1-4, scheduled to begin the week of March 27 at Clemson was postponed to April 17 due to the extension of the Rocky Flats test and changes in the glass composition. A 700 gallon tank with agitator was purchased for mixing and feeding slurry for the new WETF tests in the Envitco Melter.

Preparations for the new WETF tests continue. We are (1) working with WSRC on the glass composition for the tests; (2) development of a high-solids slurry for feeding the melter by selecting silica sources with the corrcct size distribution; and (3) preparations of the melter.

Draft copy of the WETF report was submitted to Savannah River Technology Center for review.

Interviews were held for the position of Managing Director of the Vitrification Laboratory.

Monthly copying and archiving of notebooks was conducted. 
Judith L. Bostock

April 17, 1995

Page 2

\section{B. Milestones Achieved:}

Work progressed on the Rocky Flats tests, and the final reports for the M-Area and the original WETF tests

\section{Problems Encountered:}

The power unit control on the Stir Melter continued to be a problem. The inability to control the power delayed running the RF-2 test. Bob Duerringer of Stir Melter, Inc. came to adjust and recalibrate the power control unit.

In the Rocky Flats RF-2 test in the Envitco melter, we encountered difficulties with devitrification of the glass. In addition we produced far less glass than anticipated. Since there was an unusually high emissions of salts from the meiter, it is possible that an excessive amount of sodium was lost from the glass. Material balance calculations will be made after the results of the feed, glass, and offgas analyses have been received.

Reported by T. J. Overcamp 


\section{College of Engineering}

ENVIRONMENTAL SYSTEMS ENGINEERING

Thomas J. Overcamp, PhD., P.E.

(803) 656-5573

Fax (803) 656-0672

tjuro@ese.clemson.edu

\section{Memorandum}

To: $\quad$ Dr. Judith L. Bostock, Chief Operating Officer

South Carolina Universities Research and Education Foundation

Strom Thurmond Institute

Clemson, SC 29634-5701

From: Thomas J. Overcamp

Subject: $\quad$ SCUREF Monthly Status Report, April 1995

Task Order No. 121, Phase II Vitrification Program

Date: $\quad$ May 19,1995

Enclosed is the Monthly Status Report for Task Order No. 121, "Demonstration of Vitrification on Surrogate Wasteforms in Support of DOE Process Based Delisting Petitions." This report covers the period beginning 1 April 1995 and completing 30 April 1995.

Please don't hesitate to contact me if you have any questions.

Thank you.

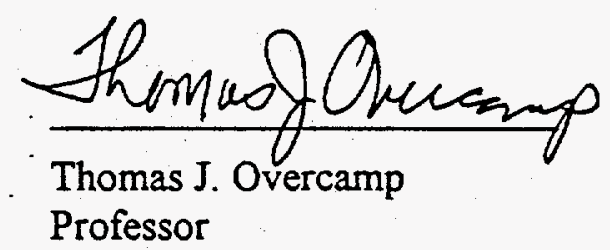

xc. J. Bailey, WSRC Procurement Administrator

D. Bickford, WSRTC Technical Representative

C. Cicero, WSRC Technical Representative

D. Helton, WSRC/DOE

T. Keinath, Clemson COE

S. S. Clipp, ESE

H. Rees, ESE 


\author{
Dr. Judith L Bostock, SCUREF \\ Strom Thurmond Institute, Clemson University \\ Clemson, South Carolina 29634-5701
}

\begin{abstract}
University: Clemson University _ P.I Dr. Thomas J. Overcamp
Project Title: Demonstration of Vitrification on Surrogate Wasteforms in Support of DOE Process Based Delisting Petitions
\end{abstract}

Period of Performance: From 4/1/95 to $4 / 30 / 95$

WSRC Technical

Representative: Dennis Bickford

\title{
A. Project Accomplishments:
}

Envitco Melter tests for Rocky Flats surrogate, which had been delayed, were run the first week of April. There were major problems arising from the high particulate levels in the exhaust gases. The particulate matter was composed largely of sodium sulfate. Due to this particulate matter, the Roots blower became clogged and jammed several times during the test. The loss of sodium resulted in a glass with a tendency to devitrify if it was cooled slowly.

At the conclusion of the Rocky Flats test, about 15 gallons of two proposed compositions of WETF sludge for the upcoming OR1-2, OR1-3, and OR $1-4$ tests were conducted. These sludges has 20 times the standard amounts of metals and about $5 \%$ yeast.

When the melter cooled, the glass devitrified forming a hard, rock-like material. Because of our inability to efficiently chip out the rock and because of refractory loss at the melt line, three of the four walls were knocked out and the melter was cleaned out. The Vision refractory had a minimum of $1^{\prime \prime}$ remaining at the electrode hole, the Monofrax CX4 had about 2" left, and the Serv 30 and the Corhart 2161 had at least 21/2" left. There was severe electrode deterioration in the test. The shortest electrode only protruded about $31 / 2$ " passed the electrode holder. Small pea-sized metals balls were noted at the bottom of the melter. This may have been caused by alloying of the molybdenum electrodes with metals in the sludge. The drain was in good shape. The melter was rebuilt with a used Corhart 2161 wall and three Findley flux block walls. New electrodes with 3 inch diameter cylindrical lug caps were installed. Since this exhausted our supply of refractory and electrodes, orders were placed for both.

In cleaning out the riser tube, an unusually large quantity of salt deposits were removed. Approximately $300 \mathrm{~kg}$ of glass was produced during the run.

The power control unit and watt transducer on the Stir Melter were repaired and recalibrated by Stir Melter so that testing can proceed in the melter. Prior to conducting the Rocky Flats test, RF2-1, a series of cascade impactor runs will be conducted using surrogate M-Area sludge.

The DC arc melter was installed and tested. Ray Schumacher of SRS was on site for the initial testing on April 20. Within 5 minutes of start-up, however, the SCRs in the power supply blew and the system shut down. A service technician from Halmar Robicon, the manufacturer of the power supply was called in. The circuit boards were removed and sent back with the technician to Pittsburgh.

On April 13 Dr. Overcamp and Sandra Clipp made a presentation to the Park Development Committee of the South Carolina Research Authority requesting the current variance allowing the existing laboratory (which does not meet Park guidelines in terms of aesthetics) be extended indefinitely. In addition, they sought an initial 
reaction to plans to build an addition (up to 3,000 more square feet) to the Vitrification Lab. They were encouraged to proceed with plans and return in July with a more specific proposal.

Testing of the new WETF compositions ORI-2, OR1-3, and OR1-4 in the Envitco melter began April 18. Testing was completed on OR1-2. In probing the melter during a hot hold at the end of this test, the electrodes had minimal wear and still had lug caps with a diameter very similar to their original 3 inches. The refractory walls experienced melt line corrosion.

New 750 gallon feed tank performed was installed for the new WETF tank. During the test, it performed flawlessly.

A second round of interviews with our first-choice candidate for the position of Managing Director of the Vitrification Laboratory was held April 20 and 21 and a decision was made to offer him the position.

Comments were received back from WSRC on the old WETF report.

Monthly copying and archiving of notebooks was conducted.

\section{B. Milestones Achieved:}

The ORI-2 and the Rocky Flats Envitco test were completed.

\section{Problems Encountered:}

The problems that occurred included the high particulate matter and devitrification in the Rocky Flats tests and the failure of the power supply on the DC arc melter as noted above.

Reported by T. J. Overcamp 


\section{College of Engineering}

ENVIRONMENTAL SYSTEMS ENGINEERING

Thomas J. Overcamp, Ph.D., P.E.

(803) 656-5573

Fax (803) 656-0672

tjvro@ese.clemson.edu

\section{Memorandum}

To: $\quad$ Edward A. Hamilton, Acting Chief Operating Officer

South Carolina Universities Research and Education Foundation

Strom Thurmond Institute

Clemson, SC 29634-5701

From: Thomas J. Overcamp

Subject: $\quad$ SCUREF Monthly Status Report, May 1995

Task Order No. 121, Phase II Vitrification Program

Date: July 17,1995

Enclosed is the Monthly Status Report for Task Order No. 121, "Demonstration of Vitrification on Surrogate Wasteforms in Support of DOE Process Based Delisting Petitions." This report covers the period beginning 1 May 1995 and completing 31 May 1995.

Please don't hesitate to contact me if you have any questions.

Thank you.

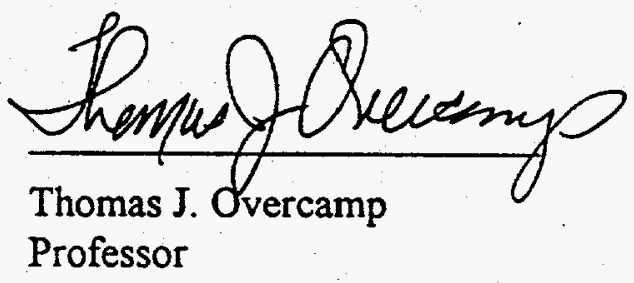

-xc. J. Bailey, WSRC Procurement Administrator

D. Bickford, WSRTC Technical Representative

C. Cicero, WSRC Technical Representative

D. Helton, WSRC/DOE

T. Keinath, Clemson COE

D. L. Erich

S. S. Clipp, ESE

H. Rees, ESE 
Edward A. Hamilton, SCUREF

Strom Thurmond Institute, Clemson University

Clemson, South Carolina 29634-5701

University: Clemson University

P.I. Dr. Thomas J. Overcamp

Project Title: Demonstration of Vitrification on Surrogate Wasteforms in Support of DOE Process Based Delisting Petitions

Period of Performance: From 5/1/95 to $5 / 30 / 95$

WSRC Technical

Representative: Dennis Bickford

\section{A. Project Accomplishments:}

The EPI DC Arc Melter was tested on the 11th after repairs were made to the power boards which had been damaged on May 4 during the scheduled "runoff." The crucible was loaded with a mix of "Aiken soil," scrap steel and limestone. The melter was heated for several hours. The next morning the crucible was opened to reveal an ash covered, irregularly shaped "blob" of gray glassy ceramic on top of a layer of metal. Throughout the gray material were metal pellets with a diameter of approximately a millimeter. The recirculated scrubber solution was brown and foamy, and a very large quantity of gray ash had clogged the offgas train. The straightening vanes in the flow meter were clogged with ash. Ray Schumacher took the crucible contents to SRS for analysis. ESE staff are cleaning and checking out the equipment.

Composition work on LANL has begun in conjunction with Connie Cicero.

Sparge tests were undertaken during the WETF run on May 23 to determine the effects of introducing nitrogen and also oxygen into the EV-16 melt chamber. It is hoped that sparging can enhance the mixing and therefor the melt rate of the feed and that the introduction of oxygen would also help with reducing conditions. The negative effects of the oxygen on the electrodes was also to be assessed.

Successful meeting with Bill Holtzscheiter, Harry Harmon, and Charlie Anderson from SRS visited on the May 10 to tour the Vit Lab and obtain a firsthand report on our program. Discussion gravitated to the suitability of ESE as the site of 9 square foot stirred melter.

The proposal for the TVS contract (WSRC \#SOS 174-EC) originally submitted March 14, had to be revised when new information was received about the power needs of the mobile lab trailer. The revisions were made and forwarded to SCUREF via the Dean's Office on May 9.

The Discflo pump which will be used in the TVS to pump slurry from the feed tank to the melter was tested here on May 11-16.

Monthly copying and archiving of notebooks was conducted. 


\section{B. Milestones Achieved:}

The WETF tests are underway in cooperation with personnel from WSRC.

The DC arc melter runoff was completed.

\section{Problems Encountered:}

A large order of cerium carbonate was delayed by the supplier due to difficulties in drying the material.

The camera lens of the camera for the stirred melter was damaged again. The cause was the plugging of the offgas line, and pressurizing the melter chamber due to the nitrogen purge and the gases given off by the melt. This slowed or stopped the nitrogen purge flow on the camera. New lenses have been ordered.

A pallet of stainless steel fittings that were from WSRC for the TVS melter project sent disappeared from our control. After searching our laboratory and a rented storage area, we reported the loss to WSRC and the Clemson University police.

WSRC is no longer able to calibrate the pressure transducers for the Vitrification Laboratory. At present we are requesting approval for continued use of the instruments.

Reported by T. J. Overcamp 


\section{College of Engineering}

ENVIRONMENTAL SYSTEMS ENGINEERING

Thomas J. Overeamp, Ph.D., P.E.

(803) 656-5573

Fax (803) 656-0672

tjvo@gese.clemsonedu

\section{Memorandum}

To: $\quad$ Edward A. Hamilton, Acting Chief Operating Officer

South Carolina Universities Research and Education Foundation

Strom Thurmond Institute

Clemson, SC 29634-5701

From: Thomas J. Overcamp

Subject: $\quad$ SCUREF Monthly Status Report, June 1995

Task Order No. 121, Phase II Vitrification Program

Date: $\quad$ August 25, 1995

Enclosed is the Monthly Status Report for Task Order No. 121, "Demonstration of Vitrification on Surrogate Wasteforms in Support of DOE Process Based Delisting Petitions." This report covers the period beginning 1 July 1995 and completing 31 July 1995.

Please don't hesitate to contact me if you have any questions.

Thank you.

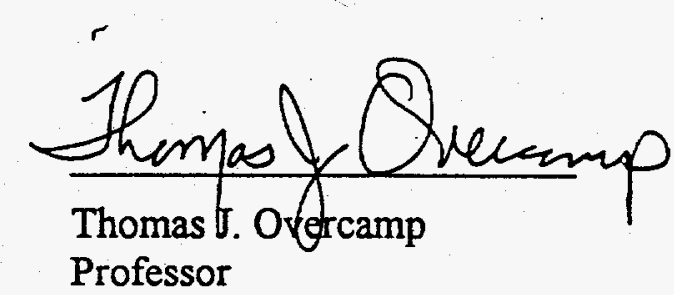

xc. J. Bailey, WSRC Procurement Administrator

D. Bickford, WSRTC Technical Representative

$\checkmark$ C. Cicero, WSRC Technical Representative

D. Helton, WSRC/DOE

T. Keinath, Clemson COE

D. L. Erich, ESE

S. S. Clipp, ESE

H. D. Rees, ESE 
Edward A. Hamilton, SCUREF

Strom Thurmond Institute, Clemson University

Clemson, South Carolina 29634-5701

University: Clemson Universitv

P.L Dr. Thomas J. Overcamp

Project Title: Demonstration of Vitrification on Surrogate Wasteforms in Support of DOE Process Based Delisting Petitions

Period of Performance: From 7/1/95 to $\underline{7 / 31 / 95}$

WSRC Technical

Representative: Dennis Bickford

\section{A. Project Accomplishments:}

Donald L. Erich joined the ESE Vitrification staff as Managing Director on July 5.

The LANL slurry development work is complete. The melter runs are scheduled for the first week in August after rebuilding the EV-16 with new refractory walls. The metal spike solution for the LANL run was prepared.

The Rocky Flats nun in the Stir Melter was problematical. Three Inconel impellers were destroyed and the resulting melt contained metal globules. Two of the impeller shafts, as well as globules of metal and one impeller. ring were sent to Jim Marra of WSRC for analysis. A chronology of the test was prepared by Rob Wilson. Glass samples from the Envitco Rocky Flats tests were also sent out for XRF and TCLP analyses.

A new disconnect box for the DC arc melter was installed to replace the one that had failed. A fourth test run in the DC arc melter was initiated but failed when the electrodes shorted out in the electrode assembly. The power cables had been exposed through abrasion when the water-cooled jackets surrounding the cables was torn by the rollers in the mechanism for raising and lowering the electrode assembly.

Plans for expanding the Vitrification Laboratory were presented to the SCRA Park Management/ Development Committee on July 13 in Columbia Approval was granted for a permanent variance to the existing structure as well as approval for the addition of 3,000 square feet of lab space. This is to be constructed with no direct costs to WSRC.

Monthly copying and archiving of notebooks was conducted as well as quarterly archiving of electronic disks and written records which are done quarterly.

\section{B. Milestones Achieved:}

The Rocky Flats Stir Melter nun was initiated.

\section{Problems Encountered}

The destruction of three impellers in the Stir Melter as discussed above. ......

DC arc melter electrodes shorted out when the jacket of the water-cooled electric cable was torn by the wheel mechanism which raises and lowers the graphite electrode assembly.. 


\section{College of Engineering}

ENVIRONMENTAL SYSTEMS ENGINEERING

Thomas J. Overcamp, Ph.D., P.E.

(803) 656-5573

Fax (803) 656-0672

ijvo@ese.clemson.edu

\section{Memorandum}

To: $\quad$ Edward A. Hamilton, Acting Chief Operating Officer

South Carolina Universities Research and Education Foundation

Strom Thurmond Institute

Clemson, SC 29634-5701

From: Thomas J. Overcamp

Subject: SCUREF Monthly Status Report, June 1995

Task Order No. 121, Phase II Vitrification Program

Date: July 18,1995

Enclosed is the Monthly Status Report for Task Order No. 121, "Demonstration of Vitrification on Surrogate Wasteforms in Support of DOE Process Based Delisting Petitions." This report covers the period beginning 1 June 1995 and completing 30 June 1995.

Please don't hesitate to contact me if you have any questions.

Thank you.

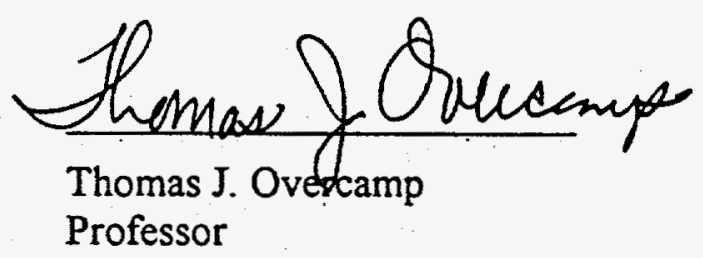

xc. J. Bailey, WSRC Procurement Administrator

D. Bickford, WSRTC Technical Representative

C. Cicero, WSRC Technical Representative

D. Helton, WSRC/DOE

T. Keinath, Clemson COE

D. L. Erich, ESE

S. S. Clipp, ESE

H. D. Rees, ESE 
Edward A. Hamilton, SCUREF

Strom Thurmond Institute, Clemson University

Clemson, South Carolina 29634-5701

University: Clemson University P.I. Dr. Thomas J. Overcamp

Project Title: Demonstration of Vitrification on Surrogate Wasteforms in Support of DOE Process Based Delisting Petitions

Period of Performance: From 6/1/95 to 6/30/95

WSRC Technical

Representative: Dennis Bickford

\section{A. Project Accomplishments:}

The WETF OR1-4 run was completed. In this test, the glass was poured in batches into the graphite crucibles. There was considerable crystallization of the glass near the centerline of the canister. WSRC notified us late in the month that WETF was being dropped for initial testing on TVS due to the difficulty of removing WETF siudge from the tank at ORR. August.

The LANL slurry development work is complete. The melter runs are scheduled for the first week in analyses.

Samples of the Rocky Flats glass and sludge from the Envitco runs has been sent to laboratories for

The DC Arc melter was run serveral times. In the first run of the month, local soil, pieces of metal, and limestone were charged to the melter. The run was not successful in that much of the metal remained unmelted and some of the soil was not melted. This may have been due to our relative inexperience in operating the melter. In a second, successful run, local soil, limestone, and sodium bicarbonate were charged to the melter. The product was nearly all glass with some small globs of metal that apparently had been reduced from iron oxides the soil. In the last run, the blower motor clogged up with salts. Consideration is being given to both short- and long-term design changes to the offgas system. A hoist was constructed to lift the graphite crucible from the melter.

- Planning of the potential Vitrification Laboratory expansion was carried out. A meeting to seek a variance from the SCRA Park Management/Development Committee will be held on July 13 in Columbia.

Planning for the runoff for the Transportable Vitrification System (TVS) was carried out in anticipation of the release of the funds for the "Checkout of the Transportable Vitrification System (SCUREF SOS174-EC). Notification of the release came at the end of the month.

Visitors from the Idaho National Engineering Laboratory's Mixed Waste Focus team visited the Laboratory on June 9. On June 12, we had a delegation of visitors from SGN in France to discuss our vitrification programs. On June 14-15, we hosted a group of Russian visitors of the $3^{\text {rd }}$ Russian Environmental Remediation Course. The latter group participated in discussions with members of our Vitrification Laboratory team, toured the laboratory and observed two of our three melters in operation, and gave talks on their remediation efforts.

A paper "Vitrification of DOE Mixed-Waste Wastewater Sludges" was presented at the $88^{\text {th }}$ Annual Meeting of the Air \& Waste Management Association in San Antonio, TX.

Monthly copying and archiving of notebooks was conducted. 
B. Milestones Achieved:

The WETF runs conducted in support of the Transportable Vitrification System.

\section{Problems Encountered:}

The crystallization of the WETF OR1-4 reported above was a problem. The cancellation of WETF as a waste for TVS makes this problem moot.

The problems experienced with the offgas will necessitate some redesign of the system in order to operate with a wide variety of wastes.

The data acquisition system (DAS) on the Envitco melter was damaged during the OR1-4 test. The damage was apparently caused by power surge due to welding on the DC arc melter. The system is being repaired and will be returned to service.

The flux block refractory suffered a significant amount of wear during the WETF runs. The life of the refractory was extended to complete the runs by blowing air on the outside of two of the refractory panels.

Reported by T. J. Overcamp

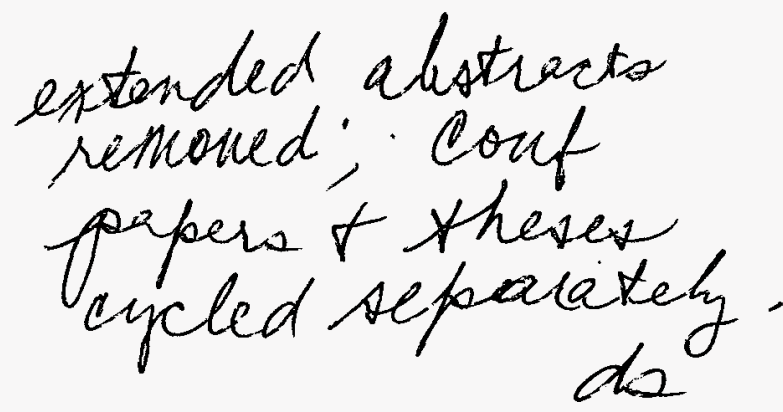

